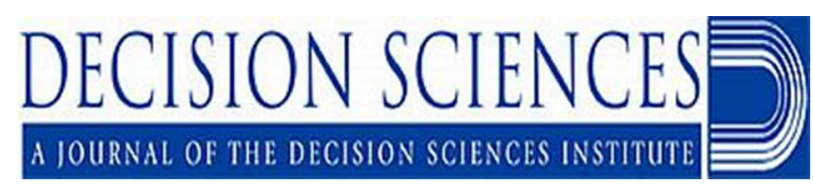

\title{
Supplier Opportunism in Buyer-Supplier New Product Development: A China-US Study of Antecedents, Consequences and Cultural/Institutional Contexts
}

\begin{tabular}{|c|l|}
\hline Journal: & Decision Sciences \\
\hline Manuscript ID: & DSJ-02-2013-008.R2 \\
\hline Wiley - Manuscript type: & Special Issue \\
\hline Topics: & $\begin{array}{l}\text { Supplier-Customer Relationship < OPERATIONS/SUPPLY CHAIN } \\
\text { MANAGEMENT, NEW PRODUCT DEVELOPMENT AND INTRODUCTION, } \\
\text { Cross-Cultural Issues < INTERNATIONAL BUSINESS }\end{array}$ \\
\hline Methodolgies: & $\begin{array}{l}\text { Survey research < EMPIRICAL METHODS, Structural Equation Modeling } \\
\text { STATISTICAL METHODS }\end{array}$ \\
\hline & $\begin{array}{l}\text { Collaborating with a supplier in a buying firm's new product development } \\
\text { (NPD) project is commonly advocated and adopted, but does not always } \\
\text { improve project performance. Some pre-existing collaboration contexts, } \\
\text { such as buyer-supplier NPD projects, are especially exposed to supplier } \\
\text { opportunism due to the uncertain nature of the collaboration process. } \\
\text { Adopting agency theory and transaction cost theory (TCT) perspectives, we } \\
\text { examine (i) contextual antecedents and project consequences of supplier } \\
\text { opportunism, and (ii) if these causal influences vary in different cultural } \\
\text { and institutional contexts. Using a survey sample of 214 United States } \\
\text { (U.S.) and 212 Chinese buying firms' responses about buyer-supplier NPD } \\
\text { projects, we find that supplier opportunism is significantly influenced by } \\
\text { the task and relational contexts. We also show that supplier opportunism } \\
\text { damages both design quality and efficiency, two aspects of project } \\
\text { performance. When comparing U.S. to China, we find that task and } \\
\text { relational contexts have a greater impact on supplier opportunism in the } \\
\text { U.S., but design efficiency is less hurt by supplier opportunism there. } \\
\text { Finally, we show challenges of preventing supplier opportunism in certain } \\
\text { NPD collaboration contexts, and offer solutions for overcoming these } \\
\text { challenges. }\end{array}$ \\
\hline \hline
\end{tabular}




\title{
SUPPLIER OPPORTUNISM IN BUYER-SUPPLIER NEW PRODUCT \\ DEVELOPMENT: A CHINA-US STUDY OF ANTECEDENTS, CONSEQUENCES AND \\ CULTURAL/INSTITUTIONAL CONTEXTS
}

\begin{abstract}
Collaborating with a supplier in a buying firm's new product development (NPD) project is commonly advocated and adopted, but does not always improve project performance. Some preexisting collaboration contexts, such as buyer-supplier NPD projects, are especially exposed to supplier opportunism due to the uncertain nature of the collaboration process. Adopting agency theory and transaction cost theory (TCT) perspectives, we examine (i) contextual antecedents and project consequences of supplier opportunism, and (ii) if these causal influences vary in different cultural and institutional contexts. Using a survey sample of 214 United States (U.S.) and 212 Chinese buying firms' responses about buyer-supplier NPD projects, we find that supplier opportunism is significantly influenced by the task and relational contexts. We also show that supplier opportunism damages both design quality and efficiency, two aspects of project performance. When comparing U.S. to China, we find that task and relational contexts have a greater impact on supplier opportunism in the U.S., but design efficiency is less hurt by supplier opportunism there. Finally, we show challenges of preventing supplier opportunism in certain NPD collaboration contexts, and offer solutions for overcoming these challenges.
\end{abstract}

Subject areas: supplier involvement, new product development, supplier opportunism, agency theory, transaction cost theory, country, culture, institutions 


\section{INTRODUCTION}

Supplier involvement in a buying firm's new product development (NPD) project is widely advocated and adopted, but it is sometimes unsuccessful (Primo and Amundson, 2002;

Koufteros, Rawski and Rupak, 2010). To explain why, the literature primarily focuses on buying firm strategies with limited attention to supplier behavior (Hartley, Zirger and Kamath, 1997; Koufteros, Vonderembse and Jayaram, 2005). However, case studies suggest that supplier opportunism may lead to unsuccessful NPD (van Echtelt, Wynstra, van Weele and Duysters, 2008). Supplier opportunism, defined as supplier self-interest-seeking behavior with guile, is a potential concern for a buying firm when managing its NPD projects (Jap and Anderson, 2003). Various forms of this behavior exist, such as supplier shirking responsibilities, hiding or providing false information, making hollow promises, or window-dressing efforts. These actions increase transaction risks for the buying firm in terms of unsatisfactory return on investment or leakage of valuable technology (Helm and Kloyer, 2004). They also create governance challenges for a buying firm as it leads the NPD initiatives (Griffith, Harmancioglu and Droge, 2009; Harmancioglu, 2009). In addition, the buying firm's responses to supplier opportunism, such as lowering commitment and intensifying monitoring, could unintentionally hurt project performance (Ulset, 1996; Andrews and Delahaye, 2000).

In this study we examine contextual antecedents, performance consequences, and moderating factors involving supplier opportunism in buyer-supplier NPD.

Although supplier opportunism is extensively examined in traditional buyer-supplier product transactions, the antecedents of supplier opportunism are not well understood in knowledge-intensive exchanges, such as buyer-supplier NPD. The literature on partner opportunism in joint innovation primarily examines the effects of governance mechanisms, not 
the effects of a collaboration context (Ulset, 1996; Oxley and Sampson, 2004; Sampson, 2004a; Carson, 2007). NPD collaboration contexts are characterized by the nature of the joint tasks (the task context) and the relationship among partners (the relational context) (Tatikonda and Rosenthal, 2000; Sobrero and Roberts, 2002; Walter, 2003).

Regarding the joint task context, uncertainty caused by either complex products or novel technology creates a dilemma for a buying firm (Johnsen, 2009). The need to better manage task uncertainty drives supplier collaboration (Petersen, Handfield and Ragatz, 2003; Ettlie and Pavlou, 2006), but at the same time, relying on a supplier to complete uncertain tasks creates information asymmetry and leaves room for opportunism (Eisenhardt, 1989; Melander, 2012).

Regarding the relational context, the literature on buyer-supplier product exchange shows that collaborative relationships are less exposed to supplier opportunism than an arm's length relationship (Jean, Kim and Sinkovics, 2012). Collaborative relationships are indicated by high levels of inter-firm coordination efforts and mutual relationship-specific investment (Parkhe, 1993; Jap, 1999). It is unclear whether the effectiveness of a collaborative relational context in curbing opportunism also exists in an intangible, less specified, and behaviorally non-transparent transaction like a buyer-supplier NPD project (Mayer, 2006). Research suggests relationshipspecific investments might unintentionally hurt collaboration outcomes in knowledge-intensive transactions due to greater safeguarding costs (Wagner, 2012). By locking both parties into a relationship, such investments can create unnecessary obligations and restrict information flows; thereby deterring inter-firm knowledge acquisition, creating collective blindness, and, ultimately, increasing the risk of opportunistic exploitation (Villena, Revilla and Choi, 2011; Zhou, in press). As such, we examine if task antecedents, specifically, product complexity and technological uncertainty, and relational antecedents, namely, inter-firm coordination efforts and 
mutual relationship-specific investment affect the buying firm's exposure to supplier opportunism.

The effect of collaboration context on opportunism and the consequences of opportunism may vary due to differences in cultural and institutional contexts among countries (Chen, Peng and Saparito, 2002; Dickson, Weaver and Hoy, 2006). A country's culture refers to the shared values and norms that influence beliefs and behavior in a society (Hofstede, 1980). A country's institutional practices relate to the political, economic, and contractual behavior patterns that regulate societal interactions (Busenitz, Gómez and Spencer, 2000). In a buyer-supplier NPD project, cultural values and institutional practices influence how a buying firm and a supplier form expectations, set goals, evaluate risks, and perceive behaviors. Each of these affects the emergence and consequence of supplier opportunism in collaboration contexts (Brown Johnson and Droege, 2004; Dickson et al., 2006; Lubatkin, Lane, Collin and Very, 2007). The literature shows that the influence of transaction context on firm behavior is culturally and institutionally contingent (Chen et al., 2002; Miranda and Kim, 2006).

We choose two countries to test the moderation effect of national context: U.S. and China. These two countries are relevant for the purpose of this study for two reasons. First, they play important roles in emerging global product development initiatives (McDonough, Kahnb and Barczaka, 2001). According to a study by the Battelle Memorial Institute, the U.S. and China have the highest research and development spending in the world (Osawa and Mozur, 2014). Second, they have very distinct cultural and institutional environments. We specifically focus on the three cultural dimensions where the two countries differ most: individualism, long term orientation, and power distance (Hofstede, 1991), as well as one distinguishing institutional dimension: formalization (Xin and Pearce, 1996; Xie, Song and Stringfellow, 1998). In so doing, 
we not only develop more generalizable results than are available from a single-country study, but we also provide useful knowledge for managers operating in global supply chains. This study also answers a call from the decision science literature to examine how China's unique cultural and institutional environments influence buyer-supplier collaboration (Zhao, Flynn and Roth, 2006).

The volatile, ambiguous, and knowledge-intensive nature of a NPD project makes it especially exposed to opportunistic behavior (Carson, Madhok and Wu, 2006; Carson, 2007). A buying firm may involve a supplier in a NPD project while unaware of the inherent complications created by the collaboration context. In order to appropriately allocate limited managerial resources among NPD collaborative instances, a buying firm needs to understand which contexts have higher risks of supplier opportunism. Therefore, in this study we examine three research questions:

(i) Does the task context indicated by product complexity and technological novelty, and the relational context indicated by coordination efforts and mutual relationship-specific investments, affect supplier opportunism in joint NPD projects?

(ii) Does supplier opportunism affect design quality and efficiency?

(iii) Do the results of (i) and (ii) differ in countries with different cultural and institutional environments, i.e., China versus U.S.?

To answer these questions, we adopt two complementary and dominant perspectives for studying opportunism: agency theory and transaction costs theory (TCT) (Bergen, Dutta and Walker Jr, 1992; Rindfleisch and Heide, 1997). Both theories treat opportunism as being evoked by certain antecedents (Bergen et al., 1992; Rindfleisch and Heide, 1997; Wang, Li, Ross Jr and Craighead, 2013). The two theories, though different, complement each other in explaining 
antecedents of opportunism in inter-organizational collaboration. Adopting more than one theoretical perspective, which has benefited the decision science literature, allows us to comprehensively understand the phenomenon and enhance our theoretical rigor (Saeed, Malhotra and Grover, 2011). This study also represents a first attempt to test the predictive validity of the two theories on opportunism in a knowledge intensive context.

The unit of analysis is a buyer-supplier NPD instance involving one buying firm and one supplying firm working together to develop a physical product. We collected a survey sample of 214 U.S. and 212 Chinese buyer-supplier NPD projects. The U.S. (China) NPD projects were conducted in the U.S. (China), and the majority of buying firm and supplier members are American (Chinese). We use two-group structural equation modeling to test country differences.

Our results contribute to the literature in the following ways. First, we extend the literature on opportunism from traditional product exchange settings to a more tacit and uncertain knowledge exchange context. Second, we show which task and relational contexts are more exposed to risks of supplier opportunism, which helps firms better govern NPD projects to minimize transaction cost. Third, answering a call from the supplier NPD involvement literature, our findings help the field understand how ongoing buyer-supplier relationships affect supplier involvement projects (van Echtelt et al., 2008; Johnsen, 2009). Fourth, this study reveals country-contextual differences that will aid multi-national corporations in adapting NPD practices in different countries (Johnsen, 2009; Perks, Kahn and Zhang, 2009). In shifting attention away from selecting suppliers with certain traits, and instead focusing on the design of the collaboration context, our research shows that supplier opportunism is inherent in certain NPD project contexts, and that supplier opportunism can explain unsatisfactory NPD project performance. 


\section{OPPORTUNISM IN INTER-ORGANIZATIONAL JOINT INNOVATION}

The decision to collaborate with external organizations in innovation is the result of an economic (or cost-benefit) calculus. When engaging in collaborative product development, a firm's innovation performance benefits from external knowledge spillovers (Dyer and Singh, 1998; Cassiman and Veugelers, 2002). At the same time, the firm needs to safeguard its research and development (R\&D) investments against partners' opportunistic behavior, such as free-riding (Kesteloot and Veugelers, 1995; Greenlee and Cassiman, 1999) and leakage of valuable technology (Teece, 1986; Pisano, 1990; Oxley and Sampson, 2004; Mol, 2005). In joint innovation, partner opportunism increases the risk of failing to obtain a fair share of the innovation return and the risk of turning the partner into a competitor by unplanned, one-sided knowledge flows. Such perceived exchange risks, in turn, motivate the firm to behave opportunistically in order to protect its benefits (Helm and Kloyer, 2004). When the benefits of acquiring knowledge outweigh the cost of safeguarding against opportunism, a firm is more likely to involve external organizations in its innovation process (Brockhoff, 1992; Veugelers, 1998).

The collaborative innovation literature has examined both proactive and reactive governance mechanisms that could be used to prevent opportunism while minimizing creativity degradation (Stump and Heide, 1996; Ulset, 1996). Proactively, firms could qualify partner trustworthiness and capability (Li, Eden, Hitt and Ireland, 2008), draft formal contracts, rely on relational mechanisms (e.g., reputation, continuity, and trust), and limit collaboration scope (Oxley and Sampson, 2004). Reactively, a firm could intensify ex post monitoring to reduce information asymmetry on partners' behavior. No matter what governance mechanism is used, 
the relational and task context influences governance effectiveness in securing collaborative benefits (Carson, Madhok, Varman and John, 2003; Helm and Kloyer, 2004; Sampson, 2004a; Carson et al., 2006; Carson, 2007).

The inter-organizational opportunism literature has extensively examined antecedents of opportunism in inter-organizational channels (Hawkins, Wittmann and Beyerlein, 2008). Factors, such as inter-organizational structures (John, 1984), dependence (Joshi and Arnold, 1997), relational norms (Joshi and Stump, 1999), formalization (Provan and Skinner, 1989), and uncertainty (Schilling and Steensma, 2002), have been shown to predict opportunism in interorganizational transactions Each of these studies alludes to the importance of examining how a transaction context influences opportunism. As John points out, it is important to understand if contextual variables might predict opportunistic behavior in situations where such behavior is feasible. Most studies only use opportunism to conceptually explain how the transaction context predicts governance mechanism and collaboration outcomes (Brockhoff, 1992; Ulset, 1996; McCutchen Jr, Swamidass and Teng, 2004; Sampson, 2004b; 2007; Li et al., 2008). The few that examine the context-opportunism link focus more on the relational characteristics than on the task characteristics of the transaction context. For instance, power and relational tenure have been shown to influence partner opportunism in joint R\&D (John, 1984; Deeds and Hill, 1999). However, it is less well known how task characteristics, such as novelty and complexity, influence partner opportunism. Furthermore, although cultural and institutional factors directly influence opportunism (Johnson, Cullen and Sakano, 1996; Lee, 1998; Skarmeas, Katsikeas and Schlegelmilch, 2002), it is less known how such factors moderate the impact of the transaction context on opportunism. To address these gaps, we adopt agency theory and TCT to explain (1) 
how the relational and task characteristics influence supplier opportunism, and (2) how these influences are moderated by cultural and institutional differences between countries.

\section{AGENCY AND GOVERNANCE PROBLEMS IN BUYER-SUPPLIER NPD}

Agency theory views agent opportunism as an outcome of principal-agent information asymmetry and goal conflicts (Eisenhardt, 1989; Kim and Mahoney, 2005). It has been used to study many types of buyer-supplier interactions where information asymmetry, opportunism, and bounded rationality exist (Bergen et al., 1992; Mishra, Heide and Cort, 1998; Sirdeshmukh, Singh and Sabol, 2002). The domain of agency theory is any relationship between "a principal and an agent who are engaged in cooperative behavior but have differing goals and differing attitudes toward risk" (Eisenhardt, 1989, pg. 59). The principal delegates decisions and/or work to the agent (Jensen and Meckling, 1976). According to the theory, incomplete information on agents' behaviors and task outcomes reduce the principal's ability to assess and correct agent behavior (i.e., increase information asymmetry), thus increasing agent opportunism (Wallace, Johnson and Umesh, 2009). Further, agency theory assumes partial principal-agent goal conflicts (Ross, 1973; Holmstrom, 1982). A principal and agent usually differ in risk preferences and task responsibilities, causing them to form different, and often conflicting goals in order to serve their self-interests (Bergen et al., 1992; Wang and Webster, 2007).

By contrast, TCT focuses on the choice of governance mechanism to minimize the transaction costs that are caused by agent opportunism (Walker and Poppo, 1991; Kim and Mahoney, 2005). Opportunism is viewed as the result of selecting the wrong governance mechanism that fails to align with exchange attributes. In essence, TCT claims that there is a relative economic efficiency of selecting hierarchy-based governance (i.e., vertical integration) 
over market-based governance (i.e., arms-length) for transactions that are more uncertain. Interorganizational collaboration is a hybrid form of governance that relies on neither hierarchy nor market to coordinate transactions (Ménard, 2004). Inter-organizational collaboration allows firms to access complementary external resources to achieve goals unattainable by any individual firm. However, for collaborations with consequential uncertainty, hybrid governance is less efficient than hierarchical governance in terms of safeguarding transaction-specific assets, evaluating partner performance, and adapting to emerging situations (Rindfleisch and Heide, 1997; Ménard, 2004). The consequence of the misalignment between a hybrid governance structure and an uncertain exchange context is a lack of control on opportunism, which causes higher transaction cost.

Therefore, in the context of buyer-supplier joint NPD projects, both agency theory and TCT predict that task and relational characteristics should influence supplier opportunism. According to agency theory, the buying firm delegates portions of the development task to a supplier. Therefore, agency theory views the buying firm as a principal and the supplier as an agent. Supplier opportunism is then caused by buyer-supplier (or principal-agent) information asymmetry and goal conflicts, both of which vary according to the task and relational factors. TCT views buyer-supplier NPD collaboration as a hybrid governance mechanism. Compared to a hierarchy (i.e. no supplier involvement in the NPD project), buyer-supplier NPD collaboration aligns better with a more certain transactional context. According to TCT, supplier opportunism, an indicator of governance-context misalignment, is higher in more uncertain task and relational contexts.

A joint NPD of car seats between Ford Motor Company and Lear Corporation for the 1996 Ford Taurus is illustrative (Walton, 1997). An uncertain task context existed because of the 
complexity of the Taurus seat and the novelty of the technologies (Guillermin, 2006). Ford found it difficult to rely on formal mechanisms to govern Lear's project activities. A short relational tenure further inhibited Ford-Lear communication and demotivated Lear commitment, both of which created room for Lear opportunism. For instance, only after numerous design defects were found during prototyping and manufacturing did Ford realize that Lear had hid information about their own severe shortage of engineering talent. Moreover, Lear's relaxed cultural style and reluctance to share designs were perceived by Ford as low commitment, which led Ford to increase its direct involvement in the project and require Lear to reorganize the Taurus team. The result was significantly higher cost for both firms (Wathne and Heide, 2000). This illustrates how task and relational contexts of a joint NPD project influence supplier opportunism that then affect collaboration outcomes.

\section{HYPOTHESIS DEVELOPMENT}

\section{Antecedents of Supplier Opportunism in Buyer-Supplier NPD}

The task environment of buyer-supplier NPD projects varies in levels of uncertainty, a key transaction attribute in both the agency and transaction cost literature (Eisenhardt, 1989; Rindfleisch and Heide, 1997; Ménard, 2004). In order to examine whether supplier opportunism is more of a problem in a more uncertain task environment, we focus on two primary factors that influence task uncertainty: product complexity and technological novelty as perceived by project members at the beginning of the project (Tatikonda and Rosenthal, 2000). Complex products have a large number of components that share many design interfaces with each other and require highly differentiated expertise for development (Flynn and Flynn, 1999). High product complexity causes equivocality, the existence of multiple and conflicting interpretations about 
task situations (Koufteros, Vonderembse and Doll, 2002). Thus, NPD projects developing complex products are usually associated with highly variable performance (Cohen, Eliashberg and Ho, 1996). Technological novelty also makes project outcomes less predictable (Tatikonda and Montoya-Weiss, 2001). With new technologies there is a lack of knowledge about the best way to solve technological problems and the exact means of implementation. This lack of knowledge makes the results of various decisions more difficult to predict. Furthermore, projects employing novel technologies often require more "organic" project structures and "experiential" approaches, which are less predictable (Eisenhardt and Tabrizi, 1995). Finally, the desirability and reliability of newer technologies have not been tested in the marketplace, which decreases the ability to predict market size and product profitability (Anderson and Tushman, 1990). Such demand uncertainty means it is more challenging for both the buying firm and the supplier to predict financial returns from the collaboration, thus increasing outcome uncertainty for both parties.

According to agency theory, product complexity and technological novelty, through increasing project outcome uncertainty, should lead to a higher level of supplier opportunism. An uncertain task environment makes it more difficult to align goals and validate supplier behavior (Eisenhardt, 1985). When developing complex products or adopting novel technology, both the buying firm and the supplier have limited information for forming their respective task strategies. This lack of information increases the chance of goal conflicts at the project outset. In addition, congruent goals set at the beginning of the project could become conflicting in later stages due to changes made by each group to adapt to the uncertain task environment. Goal conflicts between the buying firm and the supplier increase the chance that the buying firm judges the supplier as shirking responsibilities, window-dressing efforts, and making hollow promises (Das and Teng, 
1996). Furthermore, an uncertain task environment makes it difficult to detect supplier opportunism in the $R \& D$ process due to the existence of multiple explanations for the same behavior. When projects fail, it is difficult to disentangle non-compliance of partners from external sources of failure due to information asymmetry (Veugelers, 1998). Altogether, agency theory predicts that a more uncertain task environment, caused by high product complexity or technological novelty, is more exposed to supplier opportunism.

According to TCT, environmental uncertainty reduces the fit of hybrid governance mechanisms, such as inter-organizational collaboration, with the transaction context. In a NPD project, product complexity and technological novelty increase environmental uncertainty - i.e., the "unanticipated changes in circumstances surrounding an exchange" (Noordewier, John and Nevin, 1990, pg. 82). As a result, the buying firm is less capable of specifying appropriate behavior and expectations before the collaboration starts, which makes it difficult to detect opportunistic behavior (Carson et al., 2006). In addition, to avoid limiting supplier creativity, which is critical for the success of a NPD task, the buying firm often has to scale back monitoring supplier behavior after the collaboration starts, which further creates room for supplier opportunism (Carson, 2007). Such a lack of ex ante specification and ex post monitoring will be more of a problem when the task is completed by joint efforts of two firms (e.g., interorganizational collaboration), rather than by the efforts of a single firm (e.g., hierarchies). According to TCT, hierarchy is a better governance choice than a hybrid governance structure for uncertain transactions due to its higher efficiency in managing safeguards, adaptations, and problem evaluations (Rindfleisch and Heide, 1997). Thus, for a project involving complex products or novel technologies, collaborating with an external supplier is a worse governance choice than keeping the project in-house. TCT proposes that a major consequence of this 
governance-transaction misalignment is a high transaction cost as indicated by supplier opportunism (Sampson, 2004a). Consequently, both agency theory and TCT lead us to hypothesize that:

H1: (a) Product complexity and (b) technological novelty increase supplier opportunism in a buyer-supplier NPD project.

While the above task contextual factors of a NPD project increase supplier opportunism, two buyer-supplier relational attributes - coordination efforts and mutual relationship-specific investments - help reduce supplier opportunism (Jap, 1999). Developing and maintaining a cooperative relationship requires experience in joint coordination efforts and investing in relation-specific assets (Jap, 1999). Coordination efforts, in the form of joint projects tailored to buying and supplying firms' needs, enable partners to share information and processes in such a way as to capitalize on existing synergies and opportunities (Anderson and Narus, 1990). Mutual relationship-specific investments are resources dedicated to the relationship by both buying and supplying firms, such as dedicated equipment, co-located facilities, partner-specific knowledge, etc. For example, customers of the Swedish firm Tetra Pak often invest in filling equipment that is best fed with packaging material obtained from Tetra Pak (Govindarajan and Gupta, 2001). Because such investments lose value if the relationship breaks, continued exchange is expected (Heide and John, 1990), opportunistic behaviors are minimized (Nair, Narasimhan and Bendoly, 2011), and collaboration efficiencies are promised (Williamson, 1993).

From an agency theory perspective, past coordination efforts and mutual relational investment reduce supplier opportunism through lowering information asymmetry and aligning goals. With respect to coordination efforts, it allows the accumulation of partner-specific 
collaboration experience, which reduces information asymmetry in future collaboration (Hoang and Rothaermel, 2005). Specifically, recurrent collaborations allow a buying firm to gain more knowledge about the routines, assumptions, and values of a supplier, which enables accurate prediction and evaluation of supplier behavior for future projects (Jap and Anderson, 2003). Moreover, extensive information about the supplier reduces the likelihood that the buying firm will form unrealistic expectations about supplier's behavior, reducing the likelihood that the supplier will be misjudged as opportunistic. In addition, extensive coordination efforts with a supplier might also enhance the buying firm's general collaboration capability (Hoang and Rothaermel, 2005). Such enhanced collaboration capability is associated with better ex ante goal alignment and ex post monitoring, both of which demotivate supplier opportunism. Coordination efforts contribute to goal alignment by building a shared expectation of a long-term relationship (Dyer, 1997) that further reduces supplier opportunism (Parkhe, 1993). With respect to mutual relationship-specific investments (Jap and Anderson, 2003), the non-transferable nature of such investments signals a shared understanding of open-ended future interactions and a high frequency of inter-firm contact (Williamson, 1985). Both firms understand that they will have more to lose once their opportunistic behaviors are detected. Thus, supplier opportunism is directly demotivated by the higher cost of opportunism and by the belief that a buying firm will not behave opportunistically (Heide and Miner, 1992). In addition, training to understand partner routines, building inter-firm information systems, and co-locating people with similar responsibilities, builds a common language and creates communication routines. These actions reduce buyer-supplier information asymmetry and ultimately demotivate supplier opportunism (Ragatz, Handfield and Scannell, 1997). 
According to TCT, a collaborative relational context curbs supplier opportunism by enhancing the efficiency of a hybrid governance (e.g., inter-organizational collaboration) (Li et al., 2008). Because R\&D transactions are volatile, ambiguous, and knowledge-intensive by nature, they are highly exposed to risks of opportunism (Carson et al., 2006; Carson, 2007). To enhance the governing efficiency of inter-organizational R\&D transactions, TCT proposes that a collaborative inter-firm relationship helps by reducing the uncertainty in the exchange context (Rindfleisch and Heide, 1997). Because of mutual investment in relationship-specific assets, common in a collaborative relationship, the intellectual assets of either party are less exposed to unethical exploitation (Carson et al., 2003). Collaboration experience accumulated in a relationship eases adaptation to environmental change and evaluation of partner behavior (Lumineau and Henderson, 2012). Altogether, there is less room for opportunism. Following this TCT logic, coordination efforts and mutual relationship-specific investments, two indicators of a collaborative relational context, improve the governance-transaction fit, which should be reflected by a lower level of supplier opportunism. Following the above agency and TCT perspectives, we hypothesize:

H2: Buyer-supplier (a) coordination effort and (b) mutual relationship-specific investment decrease supplier opportunism in a buyer-supplier NPD project.

\section{Consequences of Supplier Opportunism in Buyer-Supplier NPD}

The presence of supplier opportunism has damaging effects on two types of project performance: design quality and efficiency. Design quality is the degree to which the product design meets performance goals related to its fitness for use (Swink and Calantone, 2004). Design efficiency is the extent to which resources are fully utilized on productive design 
activities so development cost and cycle time goals are met (Hoegl and Gemuenden, 2001). These two aspects of NPD performance capture both the effectiveness and efficiency of the joint NPD process (Wheelwright, 1992); both are important performance indicators of NPD projects (Olson, Walker Jr and Ruekert, 1995; Swink and Mabert, 2000; Hoegl and Gemuenden, 2001; Takeishi, 2001; Bstieler, 2005). Given the possible trade-off between effectiveness and efficiency in NPD projects, it is important to examine how supplier opportunism influences both design quality and efficiency (Sobrero and Roberts, 2001).

Supplier opportunism reduces design quality resulting from both the supplier's selfinterest-seeking behaviors and the buying firm's safeguarding responses. First, fraudulent, deceitful, and local-optimizing supplier behaviors jeopardize design quality by limiting the quality and quantity of knowledge contributed to the joint innovation task (Das and Rahman, 2010). Second, supplier opportunism motivates a buying firm to safeguard knowledge assets due to the higher risk of exposing them to supplier exploitation. Such safeguarding responses include withholding information, reducing resource commitment, limiting investment, and intensifying monitoring (Andrews and Delahaye, 2000). These safeguarding activities reduce the quantity and quality of the knowledge transferred and co-created, thus hurting design quality. Lastly, supplier opportunism will foster a sense of supplier untrustworthiness and in turn demotivate the buying firm from actively acquiring and absorbing knowledge shared by a supplier, resulting in fewer opportunities to improve designs (Levin and Cross, 2004).

Supplier opportunism also reduces the efficiency of the design process by making the buyersupplier NPD costly and slow. Supplier actions, such as distorting information, delaying response, and shirking obligations, reduce the speed of exchanging information and creating knowledge (Clemons and Hitt, 2004). In addition, such behaviors escalate buyer-supplier 
conflicts, reducing process efficiency by diverting project resources away from productive design work (Luo, 2007). An opportunistic supplier is more likely to increase its level of formal control when sharing knowledge with the buying firm by prioritizing its own short-term gains and losses over project progress, thus reducing process efficiency (Das and Teng, 1998). Buying firm safeguarding responses, such as intensely questioning supplier-provided information and increasing verification requirements (Das and Teng, 1998), reduce the speed of information exchange and increase the resource consumption (Zaheer, McEvily and Perrone, 1998). Thus we hypothesize:

H3: Supplier opportunism in a buyer-supplier NPD project decreases (a) design quality and (b) design efficiency.

\section{Differences between China and the United States}

Cultural and institutional factors should influence how the effects we hypothesize above differ between the U.S. and China. Culturally, the three Hofstede dimensions where the U.S. and China differ most are: individualism (score: China: 20; U.S.: 91), power distance (score: China, 80; U.S., 40), and long-term orientation (China: 118; U.S.: 29). Individualism refers to the degree of interdependence a society maintains among its members. Power distance refers to the extent to which the less powerful members of institutions and organizations within a country expect and accept that power is distributed unequally. Long-term orientation refers to the extent in which a society shows a pragmatic future-oriented perspective rather than a conventional historical shortterm point of view (Hofstede, 1991). Institutionally, China distinguishes itself most from the U.S. on the extent of reliance on informal, rather than formal, institutions to govern business transactions (Xin and Pearce, 1996; Park and Luo, 2001; Cai, Jun and Yang, 2010; Li, Xie, Teo 
and Peng, 2010b). Because cultural and institutional factors affect how firms perceive and respond to tasks and relationships, we use country differences in these factors to explain how the main effects hypothesized above vary between China and the U.S. (Brown Johnson and Droege, 2004; Dickson et al., 2006; Lubatkin et al., 2007).

Our first set of moderation hypotheses is that the two task antecedents, product complexity and technological novelty, influence supplier opportunism less in China than in the U.S. This difference exists primarily because transaction uncertainty and goal conflict will be less of a concern in China than in the U.S. Culturally, China's long-term orientation will reduce supplier sensitivity to short-term project outcome concerns (Gelfand, Spurlock, Sniezek and Shao, 2000). In placing higher value on the long-term potential benefits of collaboration, a Chinese supplier will be more willing than a U.S. supplier to align with the buying firm's expectations to invest in uncertain project activities and adopt risky strategies (Nakata and Sivakumar, 1996). In addition, China's collectivistic culture will help align buying firm and supplier interests, motivating suppliers to prioritize project targets over their own goals (Song and Montoya-Weiss, 2001). China's power distant culture causes suppliers to accept the buying firm's power in specifying goals and authorizing strategies, thus minimizing buyer-supplier transactional uncertainties and goal conflicts (Wuyts and Geyskens, 2005).

Institutionally, China's reliance on informal norms, shared values, reciprocal favors, and shared responsibility enhances the supplier's intrinsic motivation to align its goals with the buying firm's (Sundaramurthy and Lewis, 2003). In China, the reliance on interpersonal relationships to govern transactions (Perks et al., 2009) increases the informational content within the buyer-supplier NPD, enhancing the clarity of behavioral expectation ex ante and facilitating monitoring of behavior ex post. Altogether, the cultural and institutional 
characteristics of the Chinese context reduce buyer-supplier goal conflicts and information asymmetry when facing uncertain knowledge transaction outcomes. Therefore we hypothesize:

H4: The effect size of (a) product complexity and (b) technological novelty on supplier opportunism are smaller in Chinese firms than in U.S. firms.

Our second set of moderation hypotheses is that the benefits of coordination efforts and mutual relationship-specific investments in curbing supplier opportunism will be less in China as compared to those in the U.S. The primary reason for this discrepancy is that informal processes that reduce opportunism are inherent in China's cultural and institutional environments. Culturally, China's long-term orientation diverts supplier attention from short-term benefits gained through opportunism to long-term benefits resulting from a partnership. Also, China is imbued with collectivistic values that align a firm's goals by rewarding harmony and cooperation (Tjosvold, Law and Sun, 2003). The acceptance of power distance demotivates Chinese suppliers from subverting the goals of a buying firm. Because both coordination efforts and mutual relationship-specific investments aim to align goals, these factors will be less influential in curbing supplier opportunism in China than in the U.S. since goal alignment is less in question (Chen et al., 2002).

Institutional factors should create a similar effect. Chinese often rely on informal institutions to govern inter-firm transactions. For instance, interpersonal relationships and social control mechanisms influence how a buying firm selects suppliers and govern supplier behavior (Li et al., 2010b). Information and knowledge embedded in interpersonal relationships (i.e., the Guan Xi network) help reduce buyer-supplier transaction uncertainty and information asymmetry (Cai et al., 2010). Informal control mechanisms, such as trust, encourage both a buying firms and a 
supplier to openly identify, examine, and resolve problems (Luo, Liu, Zhang and Huang, 2011). Altogether, China's cultural and institutional environment makes buyer-supplier goal conflict and information asymmetry less of a concern in buyer-supplier NPD projects. As a result, having past coordination efforts and mutual relationship-specific investment are less important to curb supplier opportunism. Given these factors, we propose:

H5: The effect size of (a) previous coordination efforts and (b) mutual relationship-specific investments on supplier opportunism are smaller in Chinese firms than in U.S. firms.

Our third set of moderation hypotheses relates to how Chinese and U.S. cultural and institutional factors create more buying firm vulnerability, which affects the impact of supplier opportunism on project performance. Collectivist and power-distant cultures, like China, accept more interdependence in relations and view reliance on others as inevitable (Hofstede, 1991). For instance, Chinese buying firms might ask for supplier advice and resources in more project activities than buying firms in the U.S. would request. As a result, if suppliers delay their responses, the harm is greater in China than in the U.S. China's long-term cultural orientation means there is a bias to assume buyer-supplier NPD relationship will last over time, which suggests fewer back-up plans and alternatives available if problems arise. When an opportunistic supplier deteriorates the NPD process under such circumstances, contingency plans won't be readily available and corrective action will be difficult.

In contrast, U.S. buying firms believe in individual empowerment and independence. This short-term orientation means a buying firm in the U.S. is less likely to view a supplier as an integral, long-term partner for NPD projects. This perspective reduces the influence that supplier behavior has on project performance. Institutionally, the lack of well-developed formal 
institutions, such as contractual laws, exposes Chinese buying firms to a greater extent to supplier exploitation than U.S. buyers. Due to a lack of formal controls in China, Chinese project success is reliant on the supplier's voluntary cooperative behaviors. Without well-developed formal governance mechanisms, a high dependence on the supplier increases the damaging effects of supplier opportunism on project performance.

Furthermore, Chinese rely on informal behavioral norms in governing business exchanges, such as reciprocity in exchanging favors and fulfilling obligations (Mu et al., 2007). However, this shared value of reciprocity makes the buyer-supplier NPD vulnerable to a conflict spiral (Kumar, Scheer and Steenkamp, 1998). That is, Chinese buying firms may react punitively to supplier exploitation, aggravating the impact of supplier opportunism on project performance. In contrast, U.S. buying firm reliance on formal governance mechanisms reduces project vulnerability to supplier opportunism and demotivates a buying firm to initiate reciprocal punishment. Accordingly, U.S. cultural and institutional contexts reduce the damage of supplier opportunism on project performance. We hypothesize:

H6: The effect size of supplier opportunism on (a) design quality and (b) design efficiency are greater in Chinese firms than in U.S. firms.

$<$ INSERT FIGURE $1>$

\section{METHODOLOGY}

\section{Data Collection}

We tested the hypotheses using survey responses from manufacturing (buying) firms involved in 426 buyer-supplier NPD projects in the U.S. and China. The projects include sixteen industries producing complex and discrete products, such as airplanes, automobiles, ships, computers, 
mobile phones, and medical equipment. To control for single-respondent bias, we asked two project members from each buying firm to respond to different parts of the survey. The first respondent was asked to consider a recent NPD instance (i.e., finished within the past three years) where an external supplier collaborated with its business unit around the design of a new product in Part I of the survey. The first respondent provided information on the project's design quality and efficiency, the four antecedents to supplier opportunism, the firm size, and the timing of supplier involvement. The first respondent also provided the contact information of one key project member who actively participated in developing the product and interacted with the supplier during the collaboration. In Part II of the survey, this second respondent provided information about the interaction of each firm's project members during the project, the perceived level of supplier opportunism, and useful control variables. In this way, we separated responses for independent and dependent variables, reducing the correlations between them caused by the single respondent effect. To ensure informed respondents, respondents indicated their level of knowledge in answering the survey and only those responses that indicated "above average" or "very knowledgeable" were kept.

The initial set of respondents in the U.S. came from a commercial list provider of contact information of U.S. firm managers $(n=2,045)$, among which were 2,000 email addresses and 45 physical mail addresses. We extracted the initial set of respondents in China from member listings of manufacturer associations $(n=580)$, all of which only provided physical mail addresses. To collect data, we used two methods: online surveys and hard-copy surveys. Managers were selected based on (i) job titles that indicated engineering, manufacturing, product development, project management, or purchasing responsibilities; and (ii) industries that manufactured physical and discrete products. Survey Monkey (www.surveymonkey.com) hosted 
a two-part online survey. We sent Part I of the survey to 2,000 contacts in the U.S. by email in 2010, followed by two rounds of emails and two rounds of phone calls to non-respondents. We included project information provided by the project manager in Part I of the survey in Part II of the survey to ensure both referred to the same collaboration instance. We sent Part II of the survey by email, followed by two rounds of emails and two rounds of phone calls. First respondents specified the country of origin for project members from both firms, and we only kept responses where the majority of project members had the same nationality. This process resulted in 186 completed online U.S. surveys (Part I and II). In addition, we mailed Part I surveys to 45 managers in the U.S. and 580 to managers in China, followed by two rounds of hard-copy surveys and two rounds of phone calls, resulting in 28 and 212 completed surveys (Part I and II) from each country respectively. In total, we collected 426 out of 2,625 emailed and mailed surveys, with 214 from the U.S. and 212 from China, generating a response rate of $16.23 \%$. Demographics of the full dataset are included in the supplementary documentation.

\section{Variables and Operationalization}

The supplementary documentation shows construct measurements and literature references for all constructs used in this study. This table also presents each latent construct's factor loading, tvalue, average variance extracted (AVE), construct reliability, and Cronbach's Alpha. Each construct was measured using existing items validated by the literature.

Following previous work (Jap and Anderson, 2003), we measured supplier opportunism using the buying firm's perception. We took this approach because the buying firm "typically cannot verify their partners' guile (Jap and Ganesan, 2000) and self-reports of opportunism by partners may understate their actual opportunistic behaviors (Crosno and Dahlstrom 2008; 
Provan and Skinner 1989)" (Wang et al., 2013, pg. 112). We note that opportunistic supplier behavior from the buyer's perspective might be considered rational behavior from the supplier's perspective. For instance, while a supplier's decision to assign fewer people to a joint project is a rational supplier response to resource constraints, a buyer could view such a decision as shirking if the supplier fails to communicate with the buyer. So when interpreting our findings, we replace "supplier opportunism" with "buyer perception of supplier opportunism" to be more accurate. In order to ensure that such buyer perception is not biased by the respondent's demographic background, we tested the significance of the correlation between each of the two demographic variables: functional department (marketing, engineering, manufacturing, purchasing and others) and project role (project manager, design engineer, manufacturing engineer, and others), and buyer perception of supplier opportunism in each sample. All the four correlations turn out to be insignificant, which supports the validity of buyer perception of supplier opportunism.

We also included a set of control variables that are tangential to our focus but that may affect supplier opportunism and project performance: trust, capability complementarity, buying firm size, supplier involvement timing, contract type, project size, and task relevant expertise. Trust is an important safeguarding mechanism and should influence not only how the buying firm interprets supplier behavior and how suppliers behave (Jap and Anderson, 2003), but also should be positively correlated with design quality and efficiency (Sivadas and Dwyer, 2000). Complementary capabilities curb opportunistic behaviors and influence task performance through producing a shared sense of mutual dependence (Ganesan, 1994). Firm size influences project management capabilities, collaboration competences, and innovation potentials, and so we controlled for the number of employees $(\log )$ and sales $(\log )$. Involving suppliers early in the 
"fuzzy front end" of NPD projects has been found to enhance project outcomes (Wagner, 2012), so we also included late supplier involvement as a control variable. The type of contractual governance influences incentive alignment and opportunism (Eisenhardt, 1985; Williamson, 1985), and there are three major types that decrease in levels of hierarchical control: joint ventures, minority equity, and contractual agreements (Gulati and Singh, 1998). Because only 10 of the 426 NPD collaboration instances did not adopt contractual agreements ( 2 out of 212 in China and 8 out of 214 in the U.S.), we controlled the effect of contract type by removing the 10 cases from the final analysis. Project size could also influence group interactions and, in turn, task performance (Amason and Sapienza, 1997), so we controlled for its effect on supplier opportunism and project performance. We also controlled for task-relevant expertise of engineers because it potentially influences knowledge-intensive interactions, behaviors, and task performance (Bunderson, 2003).

We considered relational tenure as a possible factor that influences supplier opportunism. While a relationship with a long history does not necessarily mean it is collaborative in nature (McFadyen and Cannella, 2004; Villena et al., 2011), it has been shown to reflect the cooperative nature of a buyer-supplier relationship (Poppo and Zenger, 2002). However, what is essential to $\mathrm{H} 2$ is that the two relational antecedents, coordination efforts and relationship-specific investment, embody the level of cooperation in the relationship. Including relational tenure would not control for a confounding factor as much as it would create multi-collinearity problems (Graham, 2003). As such, we did not include relational tenure as a control variable.

Descriptive statistics (such as mean, standard deviation, and correlations) of the 12 constructs for the U.S. and China samples are shown in Table 1. All the items had skewness and kurtosis scores within acceptable ranges, and most were close to zero, indicating the 
acceptability of the normal distribution assumption under the SEM program. From Table 1, we noted that the average level of supplier opportunism in China (1.94) is very close to that in the U.S. (1.91). This finding implies that, on average, similar levels of supplier opportunism could be observed in buyer-supplier NPD projects conducted in the two countries.

< INSERT TABLE 1 HERE>

\section{Data Validation}

Before testing the structural model in each sample, we used two-group structural equation modeling (SEM) to assess measurement invariance across samples collected through the mail and on-line channels (Arbuckle and Wothke, 1999; Byrne, 2004). Three chi-square difference tests supported factor variance-invariance across the two samples (i.e., equivalence of factor structures, loadings, and variances), which was required to compare standardized regression coefficients across populations (Steenkamp and Baumgartner, 1998).

To test uni-dimensionality, we evaluated a CFA model with all 10 latent constructs (shown in the online supplement) in each country (Garver and Mentzer, 1999). Both samples showed the measurement model fits the data well. Specifically, in the China (U.S.) sample, the Chi-square statistic was 1542.48 (1308.71), with a degree of freedom of 981 (981). RMSEA was 0.048 (0.036), which suggested a good fit of the model with the data. All other fit indexes, such as SRMR, NNFI, CFI, and IFI, also suggested that the measurement model fits both samples well.

We assessed discriminant validity for 45 pairs of the 10 latent constructs using chi-square difference tests. In the first CFA model, the correlation among the constructs was free to vary. In the second, the correlation was fixed to a perfect correlation (1.0) (O'Leary-Kelly and Vokurka, 
1998; Garver and Mentzer, 1999). Significant chi-square difference tests suggested discriminant validity. Because a number of repeated tests were performed, we used a Bonferroni corrected pvalue of 0.1139 (Byrne, 1994; Kroes and Ghosh, 2010). All 45 pairs of chi-square difference tests were significant (p-value $<0.001139$ ), indicating discriminant validity.

We conducted different types of reliability tests using traditional reliability measures, such as Cronbach's Alpha, average variance extracted (AVE), and construct reliability (Garver and Mentzer, 1999) (see the online supplement for detailed results). All of the constructs were reliable according to their Cronbach's Alpha scores; all are greater than 0.75 and most were greater than 0.80 (Garver and Mentzer, 1999). All of the constructs had SEM construct reliability scores higher than 0.88 and variance extraction scores higher than 0.62 , which indicated acceptable reliability levels (Garver and Mentzer, 1999).

We tested for the presence of non-response bias using two methods. First, we compared the first and last 30 survey responses on all of the items of the 10 latent constructs (Lambert and Harrington, 1990; Flint and Mentzer, 1997). Second, we compared a random sample of 100 respondent firms to 100 non-respondents firms in the sampling pool by conducting t-tests on their number of employees and on their 2010 sales figures (Wagner and Kemmerling, 2010). We identified no significant differences in either analysis.

We attempted to minimize common method bias ex ante by separating the respondents answering dependent variables from those evaluating independent variables (Podsakoff, MacKenzie, Lee and Podsakoff, 2003). In addition, our two data collection methods, on-line and mail surveys, minimized the bias associated with a single collection method. To confirm that common method bias was not a significant threat to the validity of our results, we found the correlation matrix does not show highly correlated variables; the highest correlation being 0.68 , 
which is below the recommended threshold of 0.8 suggested (Bagozzi, Yi and Phillips, 1991). In addition, we adopted (Lindell and Whitney, 2001)'s approach to conduct tests on the correlation table and found that common method bias does not account for any statistically significant correlations between independent and dependent variables.

< INSERT TABLE 2 HERE>

\section{RESULTS}

We performed structural equation modeling with maximum likelihood estimation in LISREL 8.80 to test our hypotheses. In order to capture the total, direct, and indirect effects of product complexity, technological novelty, coordination efforts, and mutual relationship-specific investments on supplier opportunism, we ran three types of two-group baseline models: direct, proposed, and full, as shown in Table 3 (Liu, Huang, Luo and Zhao, 2012). In the direct model, we tested only the direct links between the four supplier opportunism antecedents and project performance. As the "Direct Model" in Table 3 shows, in both countries, product complexity and technological novelty significantly reduce design quality and efficiency, while coordination efforts and mutual relationship-specific investment significantly increase design quality and efficiency. These results suggest that developing complex products, adopting novel technology, and involving firms lacking a collaborative relationship all contribute to worse project performance in both China and the U.S.

Next, we tested the proposed model, where the four antecedents influence project performance through buyer perception of supplier opportunism. We tested hypotheses one through six by examining the significance of standardized structural regression coefficients in each group in this proposed model. As the column labeled "Proposed Model" in Table 3 
indicates, H1(a) is fully supported in that the impact of product complexity on supplier opportunism is significantly positive in both samples (China's $\beta=0.11, \mathrm{p}<0.05$ and the U.S.'s $\beta=0.17, p<0.05) .$. However, H1(b) is not supported because technological novelty's impact on supplier opportunism is not significant in either sample. We find that $\mathrm{H} 2$ (a) is strongly supported in that the negative impact of coordination efforts on supplier opportunism is significant in both samples (China's $\beta=-0.11, p<0.05$; and the U.S.'s $\beta=-0.22, p<0.01$ ). However, the results show that H2(b) is not supported in either sample. Surprisingly, the opposite effect is found in both samples: mutual relationship-specific investment is found to significantly increase the level of perceived supplier opportunism in both samples (China's $\beta=0.12, p<0.05$; and the U.S.'s $\beta=0.22, p<0.01) . H 3(a)$ and $\mathrm{H} 3(\mathrm{~b})$ are fully supported in both samples. NPD projects with a higher level of supplier opportunism, perceived by the buying firm, are associated with worse product design quality (China's $\beta=-0.17, \mathrm{p}<0.05$ and the U.S.'s $\beta=-0.17, p<0.05$ ) and less efficient design processes (China's $\beta=-0.25, \mathrm{p}<0.05$ and the U.S.'s $\beta=-0.22, p<0.05$ ) in both countries.

Finally, to test if supplier opportunism provides full mediation, we examined both the direct links between the four antecedents and project performance and the indirect links through supplier opportunism using a third model (see Table 3's "Full Model"). In comparison to the "Direct Model", the paths between the four supplier opportunism antecedents and project performance remain significant and do not change signs in both samples. Thus, following the literature (Liu et al., 2012), we conclude that supplier opportunism partially mediates the effects of product complexity, technological novelty, coordination efforts, and mutual relationshipspecific investment on design quality and efficiency in both China and the U.S. 
In order to test $\mathrm{H} 4, \mathrm{H} 5$, and H6, we adopted the two-group structural equation modeling approach (Koufteros and Marcoulides, 2006). We tested these hypotheses by a series of chisquare difference tests, each comparing a more constrained model. The path coefficient tested in the "Proposed Model" was constrained to be equal across the two samples with the nonconstrained "Proposed Model" shown in Table 3. A significant chi-square difference test suggested the tested path coefficients are statistically different across the two samples. Table 4 shows results of six chi-square difference tests. Four out of the six tests, H4(a), H5(a), H5(b), and H6(b), are significant. Specifically, product complexity has a smaller effect size on supplier opportunism in China, supporting H4(a) (China's $\beta=0.11$, $\mathrm{p}<0.05$ and the U.S.'s $\beta=0.17$, $p<0.05)$. Coordination effort is less effective in reducing supplier opportunism in the China sample, which supports H5(a) (China's $\beta=-0.11$, $\mathrm{p}<0.05$ and the U.S.'s $\beta=-0.22, p<0.01$ ). Although the effect size of mutual relationship-specific investment on supplier opportunism is smaller in China and is consistent with $\mathrm{H} 5(\mathrm{~b})$, because mutual relationship-specific investment has a positive effect on supplier opportunism in both countries, H5(b) is not supported (China's $\beta=0.12, \mathrm{p}<0.05$ and the U.S.'s $\beta=0.22, p<0.01)$. Finally, supplier opportunism is more harmful for design efficiency in China, supporting H6(b) (China's $\beta=-0.25$, $\mathrm{p}<0.05$ and the U.S.'s $\beta=-$ $0.22, p<0.05)$. Two insignificant chi-square difference tests show that the effect of technological novelty on supplier opportunism and the effect of supplier opportunism on design quality do not vary across countries, giving lack of support for H4(b) and H6(a), respectively.

To further test whether the task context increases the model's explanatory power about supplier opportunism beyond what is predicted by the relational context, we conducted a posthoc two-step procedural test. For both the proposed and full models in Table 3, we built a constrained model (Model 1) that set the path coefficients of the two task contextual variables - 
product complexity and technological novelty - to zero (Model 0). Then we conducted a chisquare difference test between Model 0 and 1. The significant chi-square statistic for the proposed model $\left(\chi^{2}(\mathrm{df})=11.05(4), \mathrm{p}\right.$-value $\left.=0.03\right)$ and the full model $\left(\chi^{2}(\mathrm{df})=14.16(4), \mathrm{p}\right.$ value $=0.01)$ suggested the two task antecedents significantly improve the fit to the data. In addition, after adding the two task antecedents the R-squares of supplier opportunism increased: in the China (U.S.) sample the proposed model increases from 0.47 to 0.51 (0.53 to 0.58$)$ and in the full model from 0.52 to 0.56 (0.61 to 0.68$)$.

\section{< INSERT TABLE 3, TABLE 4, AND FIGURE 2 HERE >}

\section{DISCUSSION}

Adopting the perspectives of agency theory and TCT, this study examines antecedents and consequences of supplier opportunism in a buyer-supplier NPD project. By comparing buying firms' survey responses regarding 206 U.S. and 210 Chinese buyer-supplier NPD projects, we find that supplier opportunism is more likely to be observed in projects involving complex products in both countries, especially in the U.S. Technological novelty does not contribute to supplier opportunism in either country. In addition, past buyer-supplier coordination helps reduce supplier opportunism in both countries, especially in the U.S. Surprisingly, buyer-supplier mutual relationship-specific investment increases supplier opportunism in both countries, but more so in the U.S. In both countries, we find that supplier opportunism reduces both design quality and design efficiency; however, design efficiency is reduced to a greater extent in China than in the U.S. 


\section{Contribution to Theory}

Contributing to the supplier NPD involvement literature, we adopt agency and TCT perspectives to theoretically explain how task and relational contexts of a buyer-supplier NPD project influence supplier opportunism. In particular, complex products, limited collaboration experience, and mutual relationship-specific investment contribute to supplier opportunism. By showing this relationship, we improve understanding of why supplier involvement is less effective in certain projects. While the majority of supplier NPD involvement literature focuses on how the collaboration is planned and executed by the buying firm (Hartley et al., 1997; Petersen, Handfield and Ragatz, 2005; Jayaram, 2008; Parker, Zsidisin and Ragatz, 2008), our study finds that the preexisting context of a project is also highly influential in affecting supplier behavior. By showing the significant impact of product complexity, a task contextual factor, on supplier opportunism, beyond the influences of the relational context, this study fills a gap in the opportunism literature that primarily focuses on relational factors (John, 1984; Deeds and Hill, 1999). Our results underscore the importance of studying the task context in order to increase the field's understanding of opportunism in inter-organizational collaborations.

In this study, we show that agency theory and TCT fail to predict the insignificant influences of technological novelty on supplier opportunism in both countries. There are two possible reasons for this unexpected result. First, suppliers might be less risk averse in projects adopting novel technology. When agreeing to venture into a novel technology together with the buying firm, suppliers accept some uncertainty in exchange for opportunities enabled by the novelty (Wells, Campbell, Valacich and Featherman, 2010). Such suppliers might be more willing to invest in risky activities to improve design solutions, reducing supplier opportunism as observed by the buying firm. Adding to the literature that examines limitations of agency theory, 
this finding challenges the assumption about different principal-agent risk preferences in a buyersupplier NPD project using novel technology. Second, in the eyes of supplier project members, technological novelty not only implies uncertain transactions, but also implies innovation opportunities. Using novel product and process technology potentially helps create higherquality designs using fewer resources, which counteracts the possible negative influences of technological novelty on project performance (Wells et al., 2010). Such co-existence of gains and losses makes technological uncertainty insignificant in affecting the transaction uncertainty that is perceived by suppliers, thus technological uncertainty ultimately fails to influence supplier opportunism.

From the perspectives of agency theory and TCT, it is surprising to observe the positive effect of mutual relationship-specific investment on supplier opportunism. Bilateral investments dedicated to the relationship are usually believed to curb opportunism by aligning incentives (Jap and Anderson, 2003). This finding shows that such investments might unintentionally hurt collaboration outcomes in knowledge-intensive transactions (Villena et al., 2011). This finding could be explained in multiple ways. Mutual relationship-specific investments may generate a sense of security that creates room for opportunistic behaviors. For instance, co-locating buying firm and supplier employees may create too much familiarity, which reduces the two firms' alertness to unexpected behavior. Excessive levels of relational security, coupled with challenges of objectively evaluating behaviors in buyer-supplier NPD, may lead both firms to reduce efforts of monitoring, vigilance, and safeguards, which allows room for opportunistic behaviors (Villena et al., 2011). In addition, suppliers may gain buying firm-specific knowledge due to the usage of mutual relationship-specific assets, such as inter-firm information systems, customized machines, closely-located plants, or cross-training. Such knowledge may motivate suppliers to 
cheat buying firms due to their perception that buyers have a lower probability of detection in a knowledge exchange and co-production context. Also, highly dedicated investment from both parties could put more at stake in the collaboration and increases expectations of each other's performance, which creates more opportunities for conflict and dissatisfaction in the relationship (Rajagopal and Rajagopal, 2009). Finally, high mutual relationship-specific investment might indicate a lack of trust because this type of investment is used to protect each firm's interest in the buyer-supplier relationship (Rinehart, Eckert, Handfield, Page and Atkin, 2004). In short, the unexpected results related to technology novelty and mutual relationship-specific investment call for more academic attention to investigate the use of agency theory and TCT in a knowledge exchange and co-production context.

Finally, this study contributes to both agency theory and TCT by considering the contingency role of national context on antecedents and consequence of agent opportunism. Our findings suggest that the influences of product complexity, mutual relationship-specific investments, and coordination experience vary in magnitude, but not in direction. Specifically, each effect is more salient in the U.S. than in China. The unexpected insignificant effects of technological novelty on supplier opportunism in both countries also show that not all buyer-supplier NPD contextual attributes' effects on supplier behaviors are culturally and institutionally contingent. Altogether, these findings refine our knowledge about how cultural and institutional contexts influence the exposure of a buyer-supplier NPD project, with certain task and relational contexts, to supplier opportunism. In addition, popular discussions of partner opportunism in traditional business exchange contexts rarely differentiate varying collaboration outcomes when examining performance implications of opportunism (Lubatkin et al., 2007). By showing that supplier opportunism influences some collaboration outcomes differently in China than in the U.S., our 
work calls for more studies to uncover the mediating mechanisms between partner opportunism and various collaboration outcomes. In this way, we could further refine our understanding of consequences of partner opportunism in inter-organizational collaboration.

\section{Managerial Insights}

This study reveals to managers the buyer-supplier NPD project characteristics that are especially likely to contribute to supplier opportunism. When developing complex products, a buying firm should expect and prepare for opportunism. Due to a greater uncertainty in outcomes, suppliers will find it more difficult to justify resources devoted to buyer-supplier NPD projects when products are complex, leading to slower supplier responsiveness and less buying firm confidence about supplier commitment. In such circumstances, buying firms should plan for supplier communication and education upon project initiation. Buying firms will need to examine what of their tacit product knowledge should be transferred to suppliers to reduce information asymmetry and to allow rational resource allocation decisions by suppliers (Li, Poppo and Zhou, 2010a). Relationally, our results will enhance the prudence of buying firms when working with suppliers in NPD projects. Beyond considering technical competencies and internal resources of suppliers, buying firms should also consider how to design the inter-firm communication channels to better manage information asymmetry. In addition, suppliers must be aware that when partners make mutual relationship-specific investments, this mutuality increases the stakes of the buyer-supplier NPD project, making buying firms highly concerned about supplier behavior. Suppliers may not be aware that their actions are under such scrutiny, so open communication is imperative to avoid inappropriate expectations and misinterpretation of behaviors. The negative association between prior buyer-supplier collaborations and supplier opportunism shows open 
communication is already tacitly embedded in the relationship to some extent. However, managers can still benefit from having explicit communication regarding behavior-related expectations to help avoid activities that can be viewed as opportunism. With the knowledge gained from this study, managers can design buyer-supplier NPD project with mechanisms that are potentially exposed to supplier opportunism in order to preempt problems related to opportunism.

Managers also must be aware that opportunism exists and damages project outcomes even in collaborative buyer-supplier projects. Many promises are made in buyer-supplier NPD, to give information, to provide feedback, to make deadlines, and to warn of problems. (Lawson, Petersen, Cousins and Handfield, 2009). Our results suggest that when suppliers are perceived as shirking promises, even if they actually are non-opportunistic, design efficiency and quality are damaged. This finding reveals to managers that rather than solely relying on choosing the right involvement strategy and selecting the right supplier prior to the collaboration, suppliers' behaviors throughout the involvement also deserve scrutiny. In addition, we believe that rather than seeing supplier opportunism as revealing supplier problems, buying firms should see it as a reflection of problems in the buyer-supplier NPD process itself. Taking this perspective would direct managerial attention to the system rather than to the behavior, which helps correct the underlying problem rather than damage the knowledge exchange and co-production processes.

Finally, managers must be aware that the country context of the project matters. Chinese suppliers are less likely to be judged as opportunistic as U.S. suppliers in uncertain buyersupplier NPD processes, yet Chinese suppliers are more influential than U.S. suppliers in damaging collaboration outcomes once they determine to behave opportunistically. This finding reveals differences that affect how managers should implement inter-firm NPD to better fit local 
cultures and institutions. In China, the Guan Xi approach to business may create biases toward giving supplier personnel the benefit-of-the-doubt where it is not deserved (Cai et al., 2010). In the U.S., the lack of interpersonal ties may create the opposite situation, generating doubt when it is undeserved. Thus, Chinese managers should rely less on their subjective judgment and more on objective measures of supplier activities when observing supplier behavior in buyer-supplier NPD processes. On the contrary, U.S. managers should openly communicate with suppliers to avoid misunderstanding and creating unnecessary conflicts. Likewise, the greater damaging effect of supplier opportunism in China than in the U.S. suggests that Chinese managers should appropriately adjust supplier roles in the project once opportunism is detected. They should also minimize unproductive buying firm responses to supplier opportunism. As global business drives managers to develop products in foreign countries, becoming aware of the unique, countryspecific contexts that influence drivers and consequences of supplier opportunism in buyersupplier NPD projects will be increasingly useful.

\section{Limitations and Future Research}

Though we have examined antecedents and consequences of supplier opportunism as judged by the buying firm in a buyer-supplier NPD context, we have not studied buying firm opportunism as observed by suppliers. Considering only supplier opportunism from the buying firm's perspective might seem natural from an agency theory perspective, which assumes the buying firm as the principal and the supplier as the agent. However, the unique nature of a buyersupplier NPD context suggests that the supplier could also perceive the buying firm as being opportunistic. A productive avenue for future studies would consider both buying firm and supplier opportunism in a buyer-supplier NPD context. Given the buying firm's significant 
interests in securing project success, it is possible that supplier opportunism is a trigger of buying firm opportunism, which further motivates supplier opportunism. There might be a reciprocal causal relationship between the two.

In this study, we only consider how supplier opportunism influences NPD project performance. Although project success is an important objective, there are other types of collaboration outcomes that deserve attention. For instance, acquiring knowledge from suppliers for future projects is an important driver (Bstieler and Hemmert, 2010). Buying firms may also be motivated by a strategic need to strengthen the buyer-supplier relationships (Shin, Collier and Wilson, 2000). Understanding whether project members are satisfied with the collaboration and whether the two firms are more capable of working together in the future are also important collaboration outcomes that can be examined in future studies.

A major aspect of this study examines the contingency roles of country. Although we have tried to select countries that play major roles in global NPD initiatives and that have unique, globally representative cultural and institutional contexts (Hofstede, 1991; Zhao et al., 2006), external validity of results from this study are still limited. While limiting the sample to two countries allows significant statistical power in testing relationships, to better understand country contingencies, future studies should sample a broader set of countries with distinct cultural and institutional settings. Such a sample would also avoid the need to use country as a proxy for cultural and institutional factors, which instead could be directly measured and whose contingency effects could be statistically tested. 
References

Amason, A. C., \& Sapienza, H. J. (1997). The Effects of Top Management Team Size and Interaction Norms on Cognitive and Affective Conflict. Journal of Management, 23(4), 495-516.

Anderson, J. C., \& Narus, J. A. (1990). A Model of Distributor Firm and Manufacturer Firm Working Partnerships. The Journal of Marketing 54(1), 42-58.

Anderson, P., \& Tushman, M. L. (1990). Technological Discontinuities and Dominant Designs: A Cyclical Model of Technological Change. Administrative Science Quarterly, 35(4), 604-633.

Andrews, K. M., \& Delahaye, B. L. (2000). Influences on Knowledge Processes in Organizational Learning: The Psychosocial Filter. Journal of Management Studies, 37(6), 797-810.

Arbuckle, J., \& Wothke, W. (1999). Amos 4 User's Reference Guide. Chicago: Smallwaters Corporation.

Bagozzi, R. P., Yi, Y., \& Phillips, L. W. (1991). Assessing Construct Validity in Organizational Research. Administrative Science Quarterly, 36(3), 421-458.

Bergen, M., Dutta, S., \& Walker Jr, O. C. (1992). Agency Relationships in Marketing: A Review of the Implications and Applications of Agency and Related Theories. The Journal of Marketing, 56(3), 1-24.

Brockhoff, K. (1992). R\&D Cooperation between Firms - a Perceived Transaction Cost Perspective. Management Science, 38(4), 514-524.

Brown Johnson, N., \& Droege, S. (2004). Reflections on the Generalization of Agency Theory: Cross-Cultural Considerations. Human Resource Management Review, 14(3), 325-335.

Bstieler, L. (2005). The Moderating Effect of Environmental Uncertainty on New Product Development and Time Efficiency*. Journal of Product Innovation Management, 22(3), 267-284.

Bstieler, L., \& Hemmert, M. (2010). Increasing Learning and Time Efficiency in Interorganizational New Product Development Teams. Journal of Product Innovation Management, 27(4), 485-499.

Bunderson, J. S. (2003). Recognizing and Utilizing Expertise in Work Groups: A Status Characteristics Perspective. Administrative Science Quarterly, 48(4), 557-591.

Busenitz, L. W., Gómez, C., \& Spencer, J. W. (2000). Country Institutional Profiles: Unlocking Entrepreneurial Phenomena. The Academy of Management Journal, 43(5), 994-1003.

Byrne, B. M. (1994). Structural Equation Modeling with Eqs and Eqs/Windows: Basic Concepts, Applications, and Programming Thousand Oaks, CA: Sage Publications

Byrne, B. M. (2004). Testing for Multigroup Invariance Using Amos Graphics: A Road Less Traveled. Structural Equation Modeling, 11(2), 272-300.

Cai, S., Jun, M., \& Yang, Z. (2010). Implementing Supply Chain Information Integration in China: The Role of Institutional Forces and Trust. Journal of Operations Management, 28(3), 257-268.

Carson, S. J. (2007). When to Give up Control of Outsourced New Product Development. Journal of Marketing, 71(1), 49-66.

Carson, S. J., Madhok, A., Varman, R., \& John, G. (2003). Information Processing Moderators of the Effectiveness of Trust-Based Governance in Interfirm R\&D Collaboration. Organization Science, 14(1), 45-56. 
Carson, S. J., Madhok, A., \& Wu, T. (2006). Uncertainty, Opportunism, and Governance: The Effects of Volatility and Ambiguity on Formal and Relational Contracting Academy of Management Journal, 49(5), 1058-1077.

Cassiman, B., \& Veugelers, R. (2002). R\&D Cooperation and Spillovers: Some Empirical Evidence from Belgium. The American Economic Review, 92(4), 1169-1184.

Chen, C. C., Peng, M. W., \& Saparito, P. A. (2002). Individualism, Collectivism, and Opportunism: A Cultural Perspective on Transaction Cost Economics. Journal of Management, 28(4), 567-583.

Clemons, E. K., \& Hitt, L. M. (2004). Poaching and the Misappropriation of Information: Transaction Risks of Information Exchange. Journal of Management Information Systems 21(2), 87-107.

Cohen, M. A., Eliashberg, J., \& Ho, T.-H. (1996). New Product Development: The Performance and Time-to-Market Tradeoff. Management Science, 42(2), 173-186.

Das, T. K., \& Rahman, N. (2010). Determinants of Partner Opportunism in Strategic Alliances: A Conceptual Framework. Journal of Business and Psychology, 25(1), 55-74.

Das, T. K., \& Teng, B.-S. (1996). Risk Types and Inter-Firm Alliance Structures. Journal of Management Studies, 33(6), 827-843.

Das, T. K., \& Teng, B.-S. (1998). Between Trust and Control: Developing Confidence in Partner Cooperation in Alliances. The Academy of Management Review, 23(3), 491-512.

Deeds, D. L., \& Hill, C. W. (1999). An Examination of Opportunistic Action within Research Alliances: Evidence from the Biotechnology Industry. Journal of Business Venturing, 14(2), 141-163.

Dickson, P. H., Weaver, K. M., \& Hoy, F. (2006). Opportunism in the R\&D Alliances of Smes: The Roles of the Institutional Environment and Sme Size. Journal of Business Venturing, 21(4), 487-513.

Dyer, J. H. (1997). Effective Interfirm Collaboration: How Firms Minimize Transaction Costs and Maximize Transaction Value. Strategic Management Journal, 18(7), 535-556.

Dyer, J. H., \& Singh, H. (1998). The Relational View: Cooperative Strategy and Sources of Interorganizational Competitive Advantage. The Academy of Management Review, 23(4), 660-679.

Eisenhardt, K. M. (1985). Control: Organizational and Economic Approaches. Management Science, 31(2), 134-149.

Eisenhardt, K. M. (1989). Agency Theory: An Assessment and Review. The Academy of Management Review, 14(1), 57-74.

Eisenhardt, K. M., \& Tabrizi, B. N. (1995). Accelerating Adaptive Processes: Product Innovation in the Global Computer Industry. Administrative Science Quarterly, 40(1), 84-110.

Ettlie, J. E., \& Pavlou, P. A. (2006). Technology-Based New Product Development Partnerships. Decision Sciences, 37(2), 117-147.

Flint, D. J., \& Mentzer, J. T. (1997). Validity in Logistics Research. Journal of Business Logistics, 18(1), 199-216.

Flynn, B. B., \& Flynn, E. J. (1999). Information-Processing Alternatives for Coping with Manufacturing Environment Complexity. Decision Sciences, 30(4), 1021-1052.

Ganesan, S. (1994). Determinants of Long-Term Orientation in Buyer-Seller Relationships. Journal of Marketing, 58(2), 1-19. 
Garver, M. S., \& Mentzer, J. T. (1999). Logistics Research Methods: Employing Structural Equation Modeling to Test for Construct Validity. Journal of Business Logistics, 20(1), 33-58.

Gelfand, M. J., Spurlock, D., Sniezek, J. A., \& Shao, L. (2000). Culture and Social Prediction the Role of Information in Enhancing Confidence in Social Predictions in the United States and China. Journal of Cross-Cultural Psychology, 31(4), 498-516.

Govindarajan, V., \& Gupta, A. K. (2001). Strategic Innovation: A Conceptual Road Map. Business Horizons, 44(4), 3-12.

Graham, M. H. (2003). Confronting Multicollinearity in Ecological Multiple Regression. Ecology, 84(11), 2809-2815.

Greenlee, P., \& Cassiman, B. (1999). Product Market Objectives and the Formation of Research Joint Ventures. Managerial and Decision Economics, 20(3), 115-130.

Griffith, D. A., Harmancioglu, N., \& Droge, C. (2009). Governance Decisions for the Offshore Outsourcing of New Product Development in Technology Intensive Markets. Journal of World Business, 44(3), 217-224.

Guillermin, O. (2006). Enabling Automotive Design Innovation for Emerging Composite Manufacturing. JEC Composites Magazine, 27, 52-54.

Gulati, R., \& Singh, H. (1998). The Architecture of Cooperation: Managing Coordination Costs and Appropriation Concerns in Strategic Alliances. Administrative Science Quarterly, 43(4), 781-814.

Harmancioglu, N. (2009). Portfolio of Controls in Outsourcing Relationships for Global New Product Development. Industrial Marketing Management, 38(4), 394-403.

Hartley, J. L., Zirger, B. J., \& Kamath, R. R. (1997). Managing the Buyer-Supplier Interface for on-Time Performance in Product Development. Journal of Operations Management, 15(1), 57-70.

Hawkins, T. G., Wittmann, C. M., \& Beyerlein, M. M. (2008). Antecedents and Consequences of Opportunism in Buyer-Supplier Relations: Research Synthesis and New Frontiers. Industrial Marketing Management, 37(8), 895-909.

Heide, J. B., \& John, G. (1990). Alliances in Industrial Purchasing: The Determinants of Joint Action in Buyer-Supplier Relationships. Journal of Marketing Research, 27(1), 24-36.

Heide, J. B., \& Miner, A. S. (1992). The Shadow of the Future: Effects of Anticipated Interaction and Frequency of Contact on Buyer-Seller Cooperation. Academy of Management Journal, 35(2), 265-291.

Helm, R., \& Kloyer, M. (2004). Controlling Contractual Exchange Risks in R\&D Interfirm Cooperation: An Empirical Study. Research Policy, 33(8), 1103-1122.

Hoang, H., \& Rothaermel, F. T. (2005). The Effect of General and Partner-Specific Alliance Experience on Joint R\&D Project Performance. Academy of Management Journal, 48(2), 332-345.

Hoegl, M., \& Gemuenden, G. H. (2001). Teamwork Quality and the Success of Innovative Projects: A Theoretical Concept. Organization Science, 12(4), 435-449.

Hofstede, G. (1980). Culture's Consequences: International Difference in Work-Related Values. Beverly Hills, CA: Sage.

Hofstede, G. (1991). Cultures and Organizations. New York: McGraw-Hill.

Holmstrom, B. (1982). Moral Hazard in Teams. The Bell Journal of Economics, 13(2), 324-340.

Jap, D. S. (1999). Pie-Expansion Efforts: Collaboration Processes in Buyer-Supplier Relationships. Journal of Marketing Research, 36(4), 461-475. 
Jap, D. S., \& Anderson, E. (2003). Safeguarding Interorganizational Performance and Continuity under Ex Post Opportunism Management Science, 49(12), 1684-1701.

Jap, S. D., \& Ganesan, S. (2000). Control Mechanisms and the Relationship Life Cycle: Implications for Safeguarding Specific Investments and Developing Commitment. Journal of marketing research, 37(2), 227-245.

Jayaram, J. (2008). Supplier Involvement in New Product Development Projects: Dimensionality and Contingency Effects. International Journal of Production Research, 46(13), 37173735.

Jean, R.-J. B., Kim, D., \& Sinkovics, R. R. (2012). Drivers and Performance Outcomes of Supplier Innovation Generation in Customer-Supplier Relationships: The Role of PowerDependence. Decision Sciences, 43(6), 1003-1038.

Jensen, M. C., \& Meckling, W. H. (1976). Theory of the Firm: Managerial Behavior, Agency Costs and Ownership Structure. Journal of financial economics, 3(4), 305-360.

John, G. (1984). An Empirical Investigation of Some Antecedents of Opportunism in a Marketing Channel. Journal of marketing research, 21(3), 278-289.

Johnsen, T. E. (2009). Supplier Involvement in New Product Development and Innovation: Taking Stock and Looking to the Future. Journal of Purchasing and Supply Management, 15(3), 187-197.

Johnson, J. L., Cullen, J. B., \& Sakano, T. (1996). Opportunistic Tendencies in Ijvs with the Japanese: The Effects of Culture, Shared Decision Making, and Relationship Age. The International Executive, 38(1), 79-94.

Joshi, A. W., \& Arnold, S. J. (1997). The Impact of Buyer Dependence on Buyer Opportunism in Buyer-Supplier Relationships: The Moderating Role of Relational Norms. Psychology \& Marketing, 14(8), 823-845.

Joshi, A. W., \& Stump, R. L. (1999). The Contingent Effect of Specific Asset Investments on Joint Action in Manufacturer-Supplier Relationships: An Empirical Test of the Moderating Role of Reciprocal Asset Investments, Uncertainty, and Trust. Journal of the Academy of Marketing Science, 27(3), 291-305.

Kesteloot, K., \& Veugelers, R. (1995). Stable R\&D Cooperation with Spillovers. Journal of Economics \& Management Strategy, 4(4), 651-672.

Kim, J., \& Mahoney, J. T. (2005). Property Rights Theory, Transaction Costs Theory, and Agency Theory: An Organizational Economics Approach to Strategic Management. Managerial and Decision Economics, 26(4), 223-242.

Koufteros, X., \& Marcoulides, G. A. (2006). Product Development Practices and Performance: A Structural Equation Modeling-Based Multi-Group Analysis. International Journal of Production Economics, 103(1), 286-307.

Koufteros, X., Vonderembse, M., \& Jayaram, J. (2005). Internal and External Integration for Product Development: The Contingency Effect of Uncertainty, Equivocality, and Platform Strategy. Decision Sciences, 36(1), 97-133.

Koufteros, X. A., Rawski, G. E., \& Rupak, R. (2010). Organizational Integration for Product Development: The Effects on Glitches, on-Time Execution of Engineering Change Orders, and Market Success. Decision Sciences, 41(1), 49-80.

Koufteros, X. A., Vonderembse, M. A., \& Doll, W. J. (2002). Integrated Product Development Practices and Competitive Capabilities: The Effects of Uncertainty, Equivocality, and Platform Strategy. Journal of Operations Management, 20(4), 331-355. 
Kroes, J. R., \& Ghosh, S. (2010). Outsourcing Congruence with Competitive Priorities: Impact on Supply Chain and Firm Performance. Journal of Operations Management, 28(2), 124143.

Kumar, N., Scheer, L. K., \& Steenkamp, J. (1998). Interdependence, Punitive Capability, and the Reciprocation of Punitive Actions in Channel Relationships. Journal of Marketing Research, 35(2), 225-235.

Lambert, D. M., \& Harrington, T. C. (1990). Measuring Nonresponse Bias in Customer Service Mail Surveys. Journal of Business Logistics, 11(2), 5-25.

Lawson, B., Petersen, K. J., Cousins, P. D., \& Handfield, R. B. (2009). Knowledge Sharing in Interorganizational Product Development Teams: The Effect of Formal and Informal Socialization Mechanisms. Journal of Product Innovation Management, 26(2), 156-172.

Lee, D.-J. (1998). Developing International Strategic Alliances between Exporters and Importers: The Case of Australian Exporters. International Journal of Research in Marketing, 15(4), 335-348.

Levin, D. Z., \& Cross, R. (2004). The Strength of Weak Ties You Can Trust: The Mediating Role of Trust in Effective Knowledge Transfer. Management Science, 50(11), 14771490.

Li, D., Eden, L., Hitt, M. A., \& Ireland, R. D. (2008). Friends, Acquaintances, or Strangers? Partner Selection in R\&D Alliances. Academy of Management Journal, 51(2), 315-334.

Li, J. J., Poppo, L., \& Zhou, K. Z. (2010a). Relational Mechanisms, Formal Contracts, and Local Knowledge Acquisition by International Subsidiaries. Strategic Management Journal, 31(4), 349-370.

Li, Y., Xie, E., Teo, H.-H., \& Peng, M. W. (2010b). Formal Control and Social Control in Domestic and International Buyer-Supplier Relationships. Journal of Operations Management, 28(4), 333-344.

Lindell, M. K., \& Whitney, D. J. (2001). Accounting for Common Method Variance in CrossSectional Research Designs. Journal of Applied Psychology, 86(1), 114-121.

Liu, Y., Huang, Y., Luo, Y., \& Zhao, Y. (2012). How Does Justice Matter in Achieving BuyerSupplier Relationship Performance? Journal of Operations Management, 30(5), 355-367.

Lubatkin, M., Lane, P. J., Collin, S., \& Very, P. (2007). An Embeddedness Framing of Governance and Opportunism: Towards a Cross-Nationally Accommodating Theory of Agency. Journal of Organizational Behavior, 28(1), 43-58.

Lumineau, F., \& Henderson, J. E. (2012). The Influence of Relational Experience and Contractual Governance on the Negotiation Strategy in Buyer-Supplier Disputes. Journal of Operations Management $(0)$.

Luo, Y. (2007). An Integrated Anti-Opportunism System in International Exchange. Journal of International Business Studies, 38(6), 855-877.

Luo, Y., Liu, Y., Zhang, L., \& Huang, Y. (2011). A Taxonomy of Control Mechanisms and Effects on Channel Cooperation in China. Academy of Marketing Science. Journal, 39(2), 307-326.

Mayer, K. J. (2006). Spillovers and Governance: An Analysis of Knowledge and Reputational Spillovers in Information Technology Academy of Management Journal, 49(1), 69-84.

McCutchen Jr, W. W., Swamidass, P. M., \& Teng, B.-S. (2004). R\&D Risk-Taking in Strategic Alliances: New Explanations for R\&D Alliances in the Biopharmaceutical Industry. MIR: Management International Review, 44(1), 53-67. 
McDonough, E. F., Kahnb, K. B., \& Barczaka, G. (2001). An Investigation of the Use of Global, Virtual, and Colocated New Product Development Teams. Journal of Product Innovation Management, 18(2), 110-120.

McFadyen, M. A., \& Cannella, A. A. (2004). Social Capital and Knowledge Creation: Diminishing Returns of the Number and Strength of Exchange Relationships. Academy of Management Journal, 47(5), 735-746.

Melander, L. (2012). Supplier Selection and Knowledge Asymmetries in New Product Development. 22nd Nordic Workshop on Interorganizational Research.

Ménard, C. (2004). The Economics of Hybrid Organizations. Journal of Institutional and Theoretical Economics JITE, 160(3), 345-376.

Miranda, S. M., \& Kim, Y.-M. (2006). Professional Versus Political Contexts: Institutional Mitigation and the Transaction Cost Heuristic in Information Systems Outsourcing. Mis Quarterly, 30(3), 725-753.

Mishra, D. P., Heide, J. B., \& Cort, S. G. (1998). Information Asymmetry and Levels of Agency Relationships. Journal of marketing research, 35(3), 277-295.

Mol, M. J. (2005). Does Being R\&D Intensive Still Discourage Outsourcing?: Evidence from Dutch Manufacturing. Research Policy, 34(4), 571-582.

Nair, A., Narasimhan, R., \& Bendoly, E. (2011). Coopetitive Buyer-Supplier Relationship: An Investigation of Bargaining Power, Relational Context, and Investment Strategies. Decision Sciences, 42(1), 93.

Nakata, C., \& Sivakumar, K. (1996). National Culture and New Product Development: An Integrative Review. Journal of Marketing, 60(1), 61-72.

Noordewier, T. G., John, G., \& Nevin, J. R. (1990). Performance Outcomes of Purchasing Arrangements in Industrial Buyer-Vendor Relationships. The Journal of Marketing, 54(4), 80-93.

O'Leary-Kelly, S. W., \& Vokurka, R. J. (1998). The Empirical Assessment of Construct Validity. Journal of Operations Management, 16(4), 387-405.

Olson, E. M., Walker Jr, O. C., \& Ruekert, R. W. (1995). Organizing for Effective New Product Development: The Moderating Role of Product Innovativeness. The Journal of Marketing, 59(1), 48-62.

Osawa, J., \& Mozur, P. (2014). The Rise of China's Innovation Machine. Wall Street Journal.

Oxley, J. E., \& Sampson, R. C. (2004). The Scope and Governance of International R\&D Alliances. Strategic Management Journal, 25(8-9), 723-749.

Park, S. H., \& Luo, Y. (2001). Guanxi and Organizational Dynamics: Organizational Networking in Chinese Firms. Strategic Management Journal, 22(5), 455-477.

Parker, D. B., Zsidisin, G. A., \& Ragatz, G. L. (2008). Timing and Extent of Supplier Integration in New Product Development: A Contingency Approach Journal of Supply Chain Management, 44(1), 71-83.

Parkhe, A. (1993). Strategic Alliance Structuring: A Game Theoretic and Transaction Cost Examination of Interfirm Cooperation. Academy of Management Journal, 36(4), 794794.

Perks, H., Kahn, K., \& Zhang, C. (2009). An Empirical Evaluation of R\&D-Marketing Npd Integration in Chinese Firms: The Guanxi Effect. The Journal of Product Innovation Management, 26(6), 640.

Petersen, K. J., Handfield, R. B., \& Ragatz, G. L. (2003). A Model of Supplier Integration into New Product Development. Journal of Product Innovation Management, 20(4), 284-299. 
Petersen, K. J., Handfield, R. B., \& Ragatz, G. L. (2005). Supplier Integration into New Product Development: Coordinating Product, Process and Supply Chain Design. Journal of Operations Management, 23(3-4), 371-388.

Pisano, G. P. (1990). The R\&D Boundaries of the Firm: An Empirical Analysis. Administrative Science Quarterly, 35(1), 153-176.

Podsakoff, P. M., MacKenzie, S. B., Lee, J.-Y., \& Podsakoff, N. P. (2003). Common Method Biases in Behavioral Research: A Critical Review of the Literature and Recommended Remedies. Journal of Applied Psychology, 88(5), 879-903.

Poppo, L., \& Zenger, T. (2002). Do Formal Contracts and Relational Governance Function as Substitutes or Complements? Strategic Management Journal, 23(8), 707-725.

Primo, M. A. M., \& Amundson, S. D. (2002). An Exploratory Study of the Effects of Supplier Relationships on New Product Development Outcomes. Journal of Operations Management, 20(1), 33-52.

Provan, K. G., \& Skinner, S. J. (1989). Interorganizational Dependence and Control as Predictors of Opportunism in Dealer-Supplier Relations. Academy of Management Journal, 32(1), 202-212.

Ragatz, G. L., Handfield, R. B., \& Scannell, T. V. (1997). Success Factors for Integrating Suppliers into New Product Development. Journal of Product Innovation Management, 14(3), 190-202.

Rajagopal, \& Rajagopal, A. (2009). Buyer-Supplier Relationship and Operational Dynamics. The Journal of the Operational Research Society, 60(3), 313-320.

Rindfleisch, A., \& Heide, J. B. (1997). Transaction Cost Analysis: Past, Present, and Future Applications. The Journal of Marketing, 61(4), 30-54.

Rinehart, L. M., Eckert, J. A., Handfield, R. B., Page, T. J., \& Atkin, T. (2004). An Assessment of Supplier-Customer Relationships. Journal of Business Logistics, 25(1), 25-62.

Ross, S. A. (1973). The Economic Theory of Agency: The Principal's Problem. The American Economic Review, 63(2), 134-139.

Saeed, K. A., Malhotra, M. K., \& Grover, V. (2011). Interorganizational System Characteristics and Supply Chain Integration: An Empirical Assessment*. Decision Sciences, 42(1), 742.

Sampson, R. C. (2004a). The Cost of Misaligned Governance in R\&D Alliances. Journal of Law, Economics, and Organization, 20(2), 484-526.

Sampson, R. C. (2004b). Organizational Choice in R\&D Alliances: Knowledge-Based and Transaction Cost Perspectives. Managerial and Decision Economics, 25(6-7), 421-436.

Sampson, R. C. (2007). R\&D Alliances and Firm Performance: The Impact of Technological Diversity and Alliance Organization on Innovation. Academy of Management Journal, 50(2), 364-386.

Schilling, M. A., \& Steensma, H. K. (2002). Disentangling the Theories of Firm Boundaries: A Path Model and Empirical Test. Organization Science, 13(4), 387-401.

Shin, H., Collier, D. A., \& Wilson, D. D. (2000). Supply Management Orientation and Supplier/Buyer Performance. Journal of Operations Management, 18(3), 317-333.

Sirdeshmukh, D., Singh, J., \& Sabol, B. (2002). Consumer Trust, Value, and Loyalty in Relational Exchanges. The Journal of Marketing, 66(1), 15-37.

Sivadas, E., \& Dwyer, F. R. (2000). An Examination of Organizational Factors Influencing New Product Success in Internal and Alliance-Based Processes. Journal of Marketing, 64(1), 31-49. 
Skarmeas, D., Katsikeas, C. S., \& Schlegelmilch, B. B. (2002). Drivers of Commitment and Its Impact on Performance in Cross-Cultural Buyer-Seller Relationships: The Importer's Perspective. Journal of International Business Studies, 33(4), 757-783.

Sobrero, M., \& Roberts, E. B. (2001). The Trade-Off between Efficiency and Learning in Interorganizational Relationships for Product Development. Management Science, 47(4), 493-511.

Sobrero, M., \& Roberts, E. B. (2002). Strategic Management of Supplier-Manufacturer Relations in New Product Development. Research Policy, 31(1), 159-182.

Song, M., \& Montoya-Weiss, M. M. (2001). The Effect of Perceived Technological Uncertainty on Japanese New Product Development. The Academy of Management Journal, 44(1), 61-80.

Steenkamp, J. B. E. M., \& Baumgartner, H. (1998). Assessing Measurement Invariance in CrossNational Consumer Research. Journal of consumer research, 25(1), 78-107.

Stump, R. L., \& Heide, J. B. (1996). Controlling Supplier Opportunism in Industrial Relationships. Journal of marketing research, 33(4), 431-441.

Sundaramurthy, C., \& Lewis, M. (2003). Control and Collaboration: Paradoxes of Governance. The Academy of Management Review, 28(3), 397-415.

Swink, M. L., \& Calantone, R. (2004). Design-Manufacturing Integration as a Mediator of Antecedents to New Product Design Quality. IEEE Transactions on Engineering Management, 51(4), 472-482.

Swink, M. L., \& Mabert, V. A. (2000). Product Development Partnerships: Balancing the Needs of Oems and Suppliers. Business Horizons, 43(3), 59-68.

Takeishi, A. (2001). Bridging Inter- and Intra-Firm Boundaries: Management of Supplier Involvement in Automobile Product Development. Strategic Management Journal, 22(5), 403-433.

Tatikonda, M. V., \& Montoya-Weiss, M. M. (2001). Integrating Operations and Marketing Perspectives of Product Innovation: The Influence of Organizational Process Factors and Capabilities on Development Performance. Management Science, 47(1), 151-172.

Tatikonda, M. V., \& Rosenthal, S. R. (2000). Technology Novelty, Project Complexity, and Product Development Project Execution Success: A Deeper Look at Task Uncertainty in Product Innovation. IEEE Transactions on Engineering Management 47(1), 74-87.

Teece, D. J. (1986). Profiting from Technological Innovation: Implications for Integration, Collaboration, Licensing and Public Policy. Research Policy, 15(6), 285-305.

Tjosvold, D., Law, K. S., \& Sun, H. F. (2003). Collectivistic and Individualistic Values: Their Effects on Group Dynamics and Productivity in China. Group Decision and Negotiation, 12(3), 243-263.

Ulset, S. (1996). R\&D Outsourcing and Contractual Governance: An Empirical Study of Commercial R\&D Projects. Journal of economic behavior \& organization, 30(1), 63-82.

van Echtelt, F. E. A., Wynstra, F., van Weele, A. J., \& Duysters, G. (2008). Managing Supplier Involvement in New Product Development: A Multiple-Case Study. Journal of Product Innovation Management, 25(2), 180-201.

Veugelers, R. (1998). Collaboration in R\&D: An Assessment of Theoretical and Empirical Findings. De Economist, 146(3), 419-443.

Villena, V. H., Revilla, E., \& Choi, T. Y. (2011). The Dark Side of Buyer-Supplier Relationships: A Social Capital Perspective. Journal of Operations Management, 29(6), 561-576. 
Wagner, S. M. (2012). Tapping Supplier Innovation. Journal of Supply Chain Management, 48(2), 37-52.

Wagner, S. M., \& Kemmerling, R. (2010). Handling Nonresponse in Logistics Research. Journal of Business Logistics, 31(2), 357-381.

Walker, G., \& Poppo, L. (1991). Profit Centers, Single-Source Suppliers, and Transaction Costs. Administrative Science Quarterly, 36(1), 66-87.

Wallace, D. W., Johnson, J. L., \& Umesh, U. (2009). Multichannels Strategy Implementation: The Role of Channel Alignment Capabilities*. Decision Sciences, 40(4), 869-900.

Walter, A. (2003). Relationship-Specific Factors Influencing Supplier Involvement in Customer New Product Development. Journal of Business Research, 56(9), 721-733.

Walton, M. (1997). When Your Partner Fails You. Fortune, 135(10), 87-89.

Wang, C. X., \& Webster, S. (2007). Channel Coordination for a Supply Chain with a RiskNeutral Manufacturer and a Loss-Averse Retailer*. Decision Sciences, 38(3), 361-389.

Wang, Q., Li, J. J., Ross Jr, W. T., \& Craighead, C. W. (2013). The Interplay of Drivers and Deterrents of Opportunism in Buyer-Supplier Relationships. Journal of the Academy of Marketing Science, 41(1), 111-131.

Wathne, K. H., \& Heide, J. B. (2000). Opportunism in Interfirm Relationships: Forms, Outcomes, and Solutions. Journal of Marketing, 64(4), 36-51.

Wells, J. D., Campbell, D. E., Valacich, J. S., \& Featherman, M. (2010). The Effect of Perceived Novelty on the Adoption of Information Technology Innovations: A Risk/Reward Perspective. Decision Sciences, 41(4), 813-843.

Wheelwright, S. C. (1992). Revolutionizing Product Development: Quantum Leaps in Speed, Efficiency, and Quality: Free Press.

Williamson, O. (1985). The Economic Institution of Capitalism. New York: Free Press.

Williamson, O. E. (1993). Calculativeness, Trust, and Economic Organization. Journal of Law and Economics, 36(April ), 453-486.

Wuyts, S., \& Geyskens, I. (2005). The Formation of Buyer-Supplier Relationships: Detailed Contract Drafting and Close Partner Selection. Journal of Marketing, 69(4), 103-117.

Xie, J., Song, X. M., \& Stringfellow, A. (1998). Interfunctional Conflict, Conflict Resolution Styles, and New Product Success: A Four-Culture Comparison. Management Science, 44(12), S192-S206.

Xin, K. K., \& Pearce, J. L. (1996). Guanxi: Connections as Substitutes for Formal Institutional Support. Academy of Management Journal, 39(6), 1641-1658.

Zaheer, A., McEvily, B., \& Perrone, V. (1998). Does Trust Matter? Exploring the Effects of Interorganizational and Interpersonal Trust on Performance. Organization Science, 9(2), 141-159.

Zhao, X., Flynn, B. B., \& Roth, A. V. (2006). Decision Sciences Research in China: A Critical Review and Research Agenda-Foundations and Overview*. Decision Sciences, 37(4), 451-496.

Zhou, K. (in press). Are Relational Ties Always Good for Knowledge Acquisition? BuyerSupplier Exchanges in China. Journal of Operations Management. 
Table 1: Descriptive statistics ${ }^{(1)}$

\begin{tabular}{|c|c|c|c|c|c|c|c|c|c|c|c|c|c|c|c|c|}
\hline & & Mean & $\mathrm{SD}$ & 1 & 2 & 3 & 4 & 5 & 6 & 7 & 8 & 9 & 10 & 11 & 12 & 13 \\
\hline 1 & $\begin{array}{l}\text { Product } \\
\text { complexity }\end{array}$ & $\begin{array}{l}3.19 \\
\mathbf{2 . 9 5}\end{array}$ & $\begin{array}{l}1.05 \\
0.97\end{array}$ & 1.00 & & & & & & & & & & & & \\
\hline 2 & $\begin{array}{l}\text { Technological } \\
\text { novelty }\end{array}$ & $\begin{array}{l}3.08 \\
\mathbf{2 . 9 6}\end{array}$ & $\begin{array}{l}0.83 \\
\mathbf{0 . 7 9}\end{array}$ & $\begin{array}{l}0.38^{* * *} \\
\mathbf{0 . 4 1} \mathbf{1}^{* * * *}\end{array}$ & 1.00 & & & & & & & & & & & \\
\hline 3 & $\begin{array}{l}\text { Relationship- } \\
\text { specific } \\
\text { investment }\end{array}$ & $\begin{array}{l}3.02 \\
\mathbf{3 . 2 7}\end{array}$ & $\begin{array}{l}1.11 \\
\mathbf{1 . 1 3}\end{array}$ & $\begin{array}{l}0.13 \\
\mathbf{0 . 3 1} * * *\end{array}$ & $\begin{array}{l}0.13 * \\
0.18 * *\end{array}$ & 1.00 & & & & & & & & & & \\
\hline 4 & $\begin{array}{l}\text { Coordination } \\
\text { effort }\end{array}$ & $\begin{array}{l}3.61 \\
\mathbf{3 . 6 2}\end{array}$ & $\begin{array}{l}1.05 \\
\mathbf{1 . 0 1}\end{array}$ & $\begin{array}{l}0.08 \\
\mathbf{0 . 1 5} *\end{array}$ & $\begin{array}{l}0.03 \\
\mathbf{0 . 0 4}\end{array}$ & $\begin{array}{l}0.47^{* * * *} \\
\mathbf{0 . 4 5} * * *\end{array}$ & 1.00 & & & & & & & & & \\
\hline 5 & $\begin{array}{l}\text { Supplier } \\
\text { opportunism }\end{array}$ & $\begin{array}{l}1.94 \\
\mathbf{1 . 9 1}\end{array}$ & $\begin{array}{l}0.95 \\
\mathbf{0 . 9 7}\end{array}$ & $\begin{array}{l}0.19^{* *} \\
\mathbf{0 . 0 8} * *\end{array}$ & $\begin{array}{l}-0.07 \\
\mathbf{0 . 0 1}\end{array}$ & $\begin{array}{l}0.13 * \\
0.15 * *\end{array}$ & $\begin{array}{l}-0.23^{* *} \\
\mathbf{- 0 . 1 5 *}\end{array}$ & 1.00 & & & & & & & & \\
\hline 6 & Design quality & $\begin{array}{l}2.23 \\
\mathbf{2 . 8 5}\end{array}$ & $\begin{array}{l}1.03 \\
\mathbf{1 . 0 4}\end{array}$ & $\begin{array}{l}-0.03 \\
\mathbf{0 . 1 6}\end{array}$ & $\begin{array}{l}-0.05 \\
\mathbf{0 . 2 1} * *\end{array}$ & $\begin{array}{l}0.21 * * \\
\mathbf{0 . 2 3} * *\end{array}$ & $\begin{array}{l}0.21^{* *} \\
0.22 * *\end{array}$ & $\begin{array}{l}-0.13^{*} \\
-\mathbf{0 . 1 9} *\end{array}$ & 1.00 & & & & & & & \\
\hline 7 & $\begin{array}{l}\text { Design } \\
\text { Efficiency }\end{array}$ & $\begin{array}{l}2.02 \\
\mathbf{2 . 5 4}\end{array}$ & $\begin{array}{l}1.01 \\
1.14\end{array}$ & $\begin{array}{l}-0.08 \\
\mathbf{0 . 0 4}\end{array}$ & $\begin{array}{l}-0.03 \\
\mathbf{0 . 0 9}\end{array}$ & $\begin{array}{l}0.14 * \\
\mathbf{0 . 0 9}\end{array}$ & $\begin{array}{l}0.08 \\
\mathbf{0 . 1 8}\end{array}$ & $\begin{array}{l}-0.16^{*} \\
\mathbf{- 0 . 1 9} * *\end{array}$ & $\begin{array}{l}0.68^{* * * *} \\
0.64^{* * * *}\end{array}$ & 1.00 & & & & & & \\
\hline 8 & Firm size & $\begin{array}{l}11.53 \\
\mathbf{1 0 . 7 1}\end{array}$ & $\begin{array}{l}2.84 \\
\mathbf{3 . 2 0}\end{array}$ & $\begin{array}{l}0.10 \\
\mathbf{0 . 0 9}\end{array}$ & $\begin{array}{l}-0.03 \\
\mathbf{0 . 0 7}\end{array}$ & $\begin{array}{l}0.06 \\
\mathbf{0 . 0 3}\end{array}$ & $\begin{array}{l}0.11 \\
\mathbf{0 . 0 9}\end{array}$ & $\begin{array}{l}0.05 \\
\mathbf{- 0 . 0 0}\end{array}$ & $\begin{array}{l}-0.16^{*} \\
\mathbf{- 0 . 0 4}\end{array}$ & $\begin{array}{l}-0.09 \\
\mathbf{0 . 0 3}\end{array}$ & 1.00 & & & & & \\
\hline 9 & $\begin{array}{l}\text { Late supplier } \\
\text { Involvement }\end{array}$ & $\begin{array}{l}2.24 \\
\mathbf{2 . 2 6}\end{array}$ & $\begin{array}{l}0.73 \\
\mathbf{0 . 7 0}\end{array}$ & $\begin{array}{l}0.03 \\
\mathbf{0 . 0 1}\end{array}$ & $\begin{array}{l}0.17^{*} \\
0.09\end{array}$ & $\begin{array}{l}0.27^{* * *} \\
\mathbf{0 . 3 0} 0^{* * *}\end{array}$ & $\begin{array}{l}0.22 * * \\
\mathbf{0 . 2 3} * *\end{array}$ & $\begin{array}{l}0.02 \\
\mathbf{0 . 0 7}\end{array}$ & $\begin{array}{l}-0.04 \\
\mathbf{- 0 . 0 2}\end{array}$ & $\begin{array}{l}-0.05 \\
\mathbf{- 0 . 0 1}\end{array}$ & $\begin{array}{l}0.07 \\
\mathbf{0 . 0 3}\end{array}$ & 1.00 & & & & \\
\hline 10 & $\begin{array}{l}\text { Task relevant } \\
\text { expertise }\end{array}$ & $\begin{array}{l}3.93 \\
\mathbf{4 . 0 6}\end{array}$ & $\begin{array}{l}0.81 \\
\mathbf{0 . 7 2}\end{array}$ & $\begin{array}{l}-0.15^{*} \\
\mathbf{0 . 0 3}\end{array}$ & $\begin{array}{l}0.13 \\
0.09\end{array}$ & $\begin{array}{l}0.22 * * \\
\mathbf{0 . 1 1}\end{array}$ & $\begin{array}{l}0.21^{* * *} \\
\mathbf{0 . 1 1}\end{array}$ & $\begin{array}{l}-0.55 * * * \\
\mathbf{- 0 . 4 4} * * *\end{array}$ & $\begin{array}{l}0.31^{* * *} \\
\mathbf{0 . 2 9} * * * *\end{array}$ & $\begin{array}{l}0.30^{* * *} \\
\mathbf{0 . 2 1} \text { ** }\end{array}$ & $\begin{array}{l}-0.09 \\
\mathbf{0 . 0 7}\end{array}$ & $\begin{array}{l}0.09 \\
0.03\end{array}$ & 1.00 & & & \\
\hline 11 & $\begin{array}{l}\text { Capability } \\
\text { complementarity }\end{array}$ & $\begin{array}{l}4.08 \\
\mathbf{4 . 1 3}\end{array}$ & $\begin{array}{l}0.86 \\
\mathbf{0 . 8 2}\end{array}$ & $\begin{array}{l}-0.09 \\
\mathbf{0 . 1 1}\end{array}$ & $\begin{array}{l}0.13 \\
0.09\end{array}$ & $\begin{array}{l}0.20^{* *} \\
\mathbf{0 . 2 0} * *\end{array}$ & $\begin{array}{l}0.24 * * \\
\mathbf{0 . 1 9} * *\end{array}$ & $\begin{array}{l}-0.55^{* * * *} \\
\mathbf{- 0 . 5 1} \mathbf{1}^{* * * *}\end{array}$ & $\begin{array}{l}0.26^{* * *} \\
0.27^{* * * *}\end{array}$ & $\begin{array}{l}0.24 * * * \\
\mathbf{0 . 2 2} * *\end{array}$ & $\begin{array}{l}-0.16^{*} \\
-\mathbf{- 0 . 0 6}\end{array}$ & $\begin{array}{l}0.11 \\
\mathbf{0 . 1 7 *}\end{array}$ & $\begin{array}{l}0.65^{* * *} \\
\mathbf{0 . 5 6} \mathbf{6}^{* * * *}\end{array}$ & 1.00 & & \\
\hline 12 & Trust & $\begin{array}{l}4.04 \\
\mathbf{4 . 0 7}\end{array}$ & $\begin{array}{l}0.82 \\
\mathbf{0 . 8 0}\end{array}$ & $\begin{array}{l}-0.12 \\
\mathbf{0 . 0 7}\end{array}$ & $\begin{array}{l}0.08 \\
\mathbf{- 0 . 0 3}\end{array}$ & $\begin{array}{l}0.10 \\
\mathbf{- 0 . 0 1}\end{array}$ & $\begin{array}{l}0.22 * * \\
\mathbf{0 . 0 4}\end{array}$ & $\begin{array}{l}-0.67 * * * \\
-\mathbf{0 . 1 9} \mathbf{9}^{* *}\end{array}$ & $\begin{array}{l}0.13 \\
\mathbf{- 0 . 0 1}\end{array}$ & $\begin{array}{l}0.19 * * \\
0.05\end{array}$ & $\begin{array}{l}-0.03 \\
\mathbf{0 . 0 2}\end{array}$ & $\begin{array}{l}0.00 \\
\mathbf{- 0 . 1 0}\end{array}$ & $\begin{array}{l}0.58^{* * *} \\
\mathbf{- 0 . 0 1}\end{array}$ & $\begin{array}{l}0.65^{* * *} \\
\mathbf{0 . 0 5}\end{array}$ & 1.00 & \\
\hline 13 & Project size & $\begin{array}{l}1.81 \\
1.73\end{array}$ & $\begin{array}{l}0.87 \\
\mathbf{0 . 7 5}\end{array}$ & $\begin{array}{l}0.05 * \\
\mathbf{0 . 0 9 *}\end{array}$ & $\begin{array}{l}0.07 * * \\
\mathbf{0 . 1 2} *\end{array}$ & $\begin{array}{l}0.01 \\
\mathbf{0 . 0 4}\end{array}$ & $\begin{array}{l}0.08 \\
\mathbf{0 . 0 3}\end{array}$ & $\begin{array}{l}0.04 \\
\mathbf{0 . 0 6}\end{array}$ & $\begin{array}{l}0.11 \\
\mathbf{0 . 0 2}\end{array}$ & $\begin{array}{l}0.08 \\
\mathbf{0 . 1 0}\end{array}$ & $\begin{array}{l}0.01 \\
\mathbf{0 . 0 5} *\end{array}$ & $\begin{array}{l}0.05 \\
\mathbf{0 . 1 0}\end{array}$ & $\begin{array}{l}0.12 \\
\mathbf{0 . 0 5}\end{array}$ & $\begin{array}{l}0.01 \\
\mathbf{0 . 0 6}\end{array}$ & $\begin{array}{l}0.03 \\
\mathbf{0 . 0 1}\end{array}$ & 1.00 \\
\hline
\end{tabular}

$p<<.05, * *<<0.01, * * * p<0.001, \mathrm{~N}(\mathrm{U} . \mathrm{S})=206,. \mathrm{~N}($ China $)=210$
(1) Italic numbers represent the China sample, while bolded numbers represent the U.S. sample. 


\section{Table 2: Data validation tests and results}

\begin{tabular}{|c|c|c|c|c|}
\hline Validation tests & Statistical methods & \multicolumn{3}{|c|}{ Results } \\
\hline \multirow{4}{*}{ Measurement invariance } & \multirow{4}{*}{$\begin{array}{l}\text { Two-group SEM (Arbuckle and Wothke, 1999; Byrne, 2001; Little, 1997). A test of configural invariance is } \\
\text { a test of a "weak factorial invariance" null hypothesis (Horn and McArdle 1992) in which the same pattern } \\
\text { of fixed and free factor loadings is specified for each group. A test of metric invariance (or equal loadings), } \\
\text { after configural invariance has been confirmed, is that loadings for like items are invariance across } \\
\text { populations. A test of factor variance invariance is to test whether factor variances are invariant across } \\
\text { populations. A test of full invariance, after metric invariance has been established, is a test that error } \\
\text { variances are invariant across populations. }\end{array}$} & $\begin{array}{l}\text { Configural } \\
\text { invariance }\end{array}$ & \multicolumn{2}{|c|}{ RMSEA $=0.044, \mathrm{NFI}=0.92, \mathrm{CFI}=0.97$, Chi-square $(1973)=2894$} \\
\hline & & $\begin{array}{l}\text { Metric } \\
\text { invariance }\end{array}$ & \multicolumn{2}{|c|}{$\begin{array}{l}\text { Chi-square difference }(37)=39.48, \mathrm{p} \text {-value }=0.36 \\
\text { RMSEA }=0.044, \mathrm{NFI}=0.91, \mathrm{CFI}=0.97\end{array}$} \\
\hline & & $\begin{array}{l}\text { Factor } \\
\text { variance } \\
\text { invariance }\end{array}$ & \multicolumn{2}{|c|}{$\begin{array}{l}\text { Chi-square difference }(10)=8.99, \mathrm{p}-\text { value }=0.53 \\
\text { RMSEA }=0.045, \mathrm{NFI}=0.91, \mathrm{CFI}=0.97\end{array}$} \\
\hline & & $\begin{array}{l}\text { Full } \\
\text { invariance }\end{array}$ & \multicolumn{2}{|c|}{$\begin{array}{l}\text { Chi-square difference }(44)=160.62, \mathrm{p} \text {-value }<0.001 \\
\text { RMSEA }=0.045, \mathrm{NFI}=0.91, \mathrm{CFI}=0.97\end{array}$} \\
\hline & & & China & U.S. \\
\hline Unidimensionality & $\begin{array}{l}\text { A CFA model with all the } 10 \text { latent constructs is tested in the two sub-samples is evaluated (Garver and } \\
\text { Mentzer, 1999). }\end{array}$ & $\begin{array}{r}\text { Chi-s } \\
\text { RMSE } \\
\text { confiden } \\
(0.0 \\
(\text { RMSEA }<0 \\
\text { NNFI }=0\end{array}$ & $\begin{array}{l}\text { uare }(981)=1542.61 \\
A=0.048,90 \text { percent } \\
\text { e interval for RMSEA } \\
3,0.054) \text {, P-value } \\
05)=0.69, \text { SRMR }=0.066 \\
7, \text { CFI }=0.97, \text { IFI }=0.97\end{array}$ & $\begin{array}{c}\text { Chi-square }(981)=1309.63 \\
\text { RMSEA }=0.035,90 \text { percent } \\
\text { confidence interval for RMSEA } \\
(0.030,0.041), \text { P-value } \\
\text { (RMSEA }<0.05)=1.00 \\
\text { SRMR }=0.054, \text { NNFI }=0.97 \\
\text { CFI }=0.97, \text { IFI }=0.97\end{array}$ \\
\hline Discriminant validity & $\begin{array}{l}\text { Chi-square difference tests comparing two models for each of the } 45 \text { pairs of the } 10 \text { constructs: In the first } \\
\text { CFA model, the correlation between the constructs is free to vary. In the second, the correlation is fixed to a } \\
\text { perfect correlation (1.0) (Garver and Mentzer 1999; O'Leary-Kelly and Vokurka 1998). Significant chi- } \\
\text { square difference tests suggest discriminant validity. A Bonferroni corrected p-value } 0.00093 \text { is used since } \\
\text { we are performing a number of repeated tests (Byrne 1994, Kroes and Ghosh 2010). }\end{array}$ & \multicolumn{3}{|c|}{$\begin{array}{l}\text { All the } 45 \text { pairs of chi-square difference tests turned out to be significance ( } p \text { - } \\
\text { value }<0.0011 \text { ), indicating discriminant validity. }\end{array}$} \\
\hline Reliability & $\begin{array}{l}\text { To test reliability, we used both the traditional reliability measures, such as Cronbach's Alpha, Spearman } \\
\text { Brown (unequal-length), and Guttman Split-Half, and SEM construct reliability measures, such as construct } \\
\text { reliability and variance extracted (Garver and Mentzer 1999). }\end{array}$ & \multicolumn{3}{|c|}{$\begin{array}{l}\text { All the constructs' Cronbach's Alpha are higher than, indicating reliable } \\
\text { scales (Garver and Mentzer 1999). In addition, all the scales have Spearman } \\
\text { Brown coefficients higher than } 0.70 \text { and Guttman Split-Half scores higher } \\
\text { than 0.60. All the SEM construct reliability scores higher than } 0.70 \text { and } \\
\text { variance extraction scores higher than } 0.50 \text { (Garver and Mentzer 1999). }\end{array}$} \\
\hline
\end{tabular}


Table 3: SEM analysis results ${ }^{(1)}$

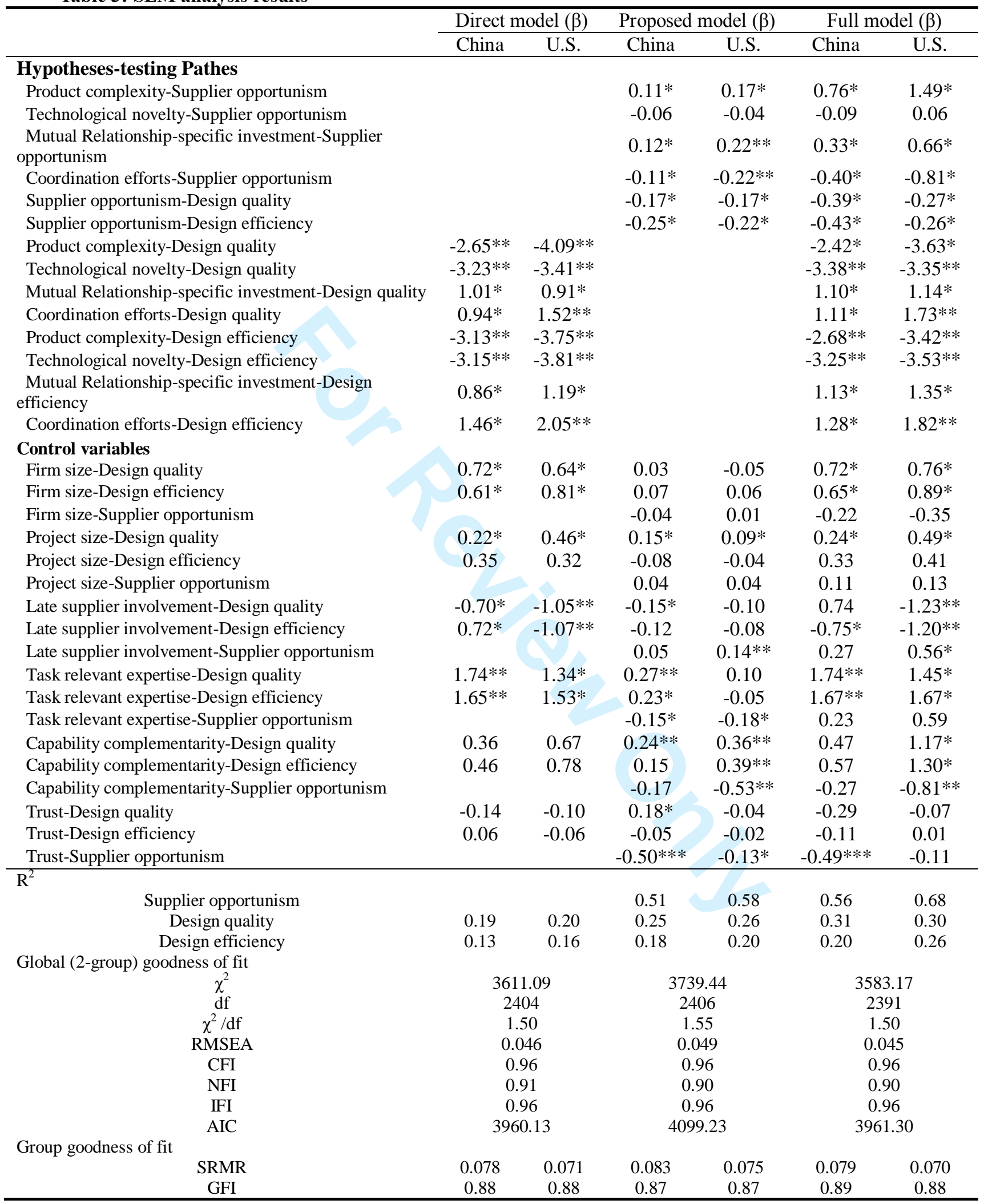

(1) All the numbers are standardized path coefficients. (S) signifies significant differences of the coefficients in the two samples. ${ }^{*} \mathrm{p}<0.05,{ }^{*} \mathrm{p}<0.01,{ }^{*} * \mathrm{p} p<0.001, \mathrm{n}$ (China) $=210, \mathrm{n}($ U.S. $)=206$ 
Table 4: Results of the chi-square difference tests for Hypotheses 7, 8, and 9

\begin{tabular}{|c|c|c|c|c|c|c|}
\hline \multirow[b]{2}{*}{ Hypotheses } & \multicolumn{2}{|c|}{$\begin{array}{l}\text { Standardized path } \\
\text { coefficient in the } \\
\text { baseline model }\end{array}$} & \multirow[b]{2}{*}{ The path constrained to be equal } & \multirow{2}{*}{$\begin{array}{l}\text { Chi-square } \\
\text { difference } \\
\text { statistics } \\
\end{array}$} & \multirow[b]{2}{*}{ p-value } & \multirow[b]{2}{*}{ Result } \\
\hline & China & U.S. & & & & \\
\hline $\mathrm{H} 4 \mathrm{a}$ & 0.11 & 0.17 & $\begin{array}{c}\text { Product complexity->Supplier } \\
\text { opportunism }\end{array}$ & $\begin{array}{c}\text { Chi-square } \\
(1)=3.91\end{array}$ & 0.05 & Supported \\
\hline $\mathrm{H} 4 \mathrm{~b}$ & n.s. & n.s. & $\begin{array}{c}\text { Technological novelty->Supplier } \\
\text { opportunism }\end{array}$ & $\begin{array}{l}\text { Chi-square } \\
(1)=1.52\end{array}$ & 0.22 & $\begin{array}{c}\text { Not } \\
\text { supported }\end{array}$ \\
\hline H5a & -0.11 & -0.22 & $\begin{array}{c}\text { Coordination effort- }>\text { Supplier } \\
\text { opportunism }\end{array}$ & $\begin{array}{l}\text { Chi-square } \\
(1)=4.96\end{array}$ & 0.03 & Supported \\
\hline $\mathrm{H} 5 \mathrm{~b}$ & 0.12 & 0.22 & $\begin{array}{c}\text { Mutual Relationship-specific } \\
\text { investment->Supplier opportunism }\end{array}$ & $\begin{array}{c}\text { Chi-square } \\
(1)=5.85\end{array}$ & 0.02 & $\begin{array}{c}\text { Not } \\
\text { supported }\end{array}$ \\
\hline H6a & -0.17 & -0.17 & $\begin{array}{l}\text { Supplier opportunism->Design } \\
\text { quality }\end{array}$ & $\begin{array}{l}\text { Chi-square } \\
(1)=1.12\end{array}$ & 0.29 & $\begin{array}{c}\text { Not } \\
\text { supported }\end{array}$ \\
\hline H6b & -0.25 & -0.22 & $\begin{array}{l}\text { Supplier opportunism->Design } \\
\text { efficiency }\end{array}$ & $\begin{array}{l}\text { Chi-square } \\
(1)=4.75\end{array}$ & 0.03 & Supported \\
\hline
\end{tabular}




\section{Figure 1: Conceptual Model}

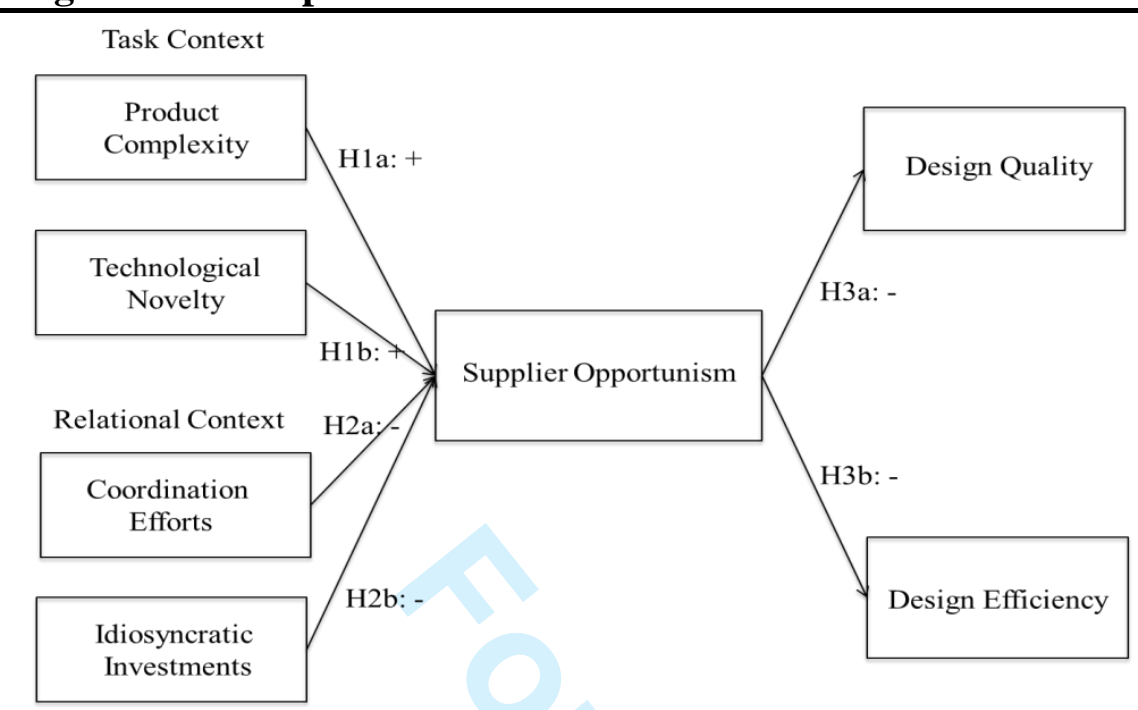

H4a-H4b: Effect sizes of technical antecedents on supplier opportunism are smaller in China compared to those in the US

H5a-H5b: Effect sizes of relational antecedents on supplier opportunism are smaller in China compared to those in the US

H6a-H6b: Effect sizes of supplier opportunism on design quality and efficiency are greater in China compared to those in the US

\section{Figure 2: Results}

\section{U.S.}

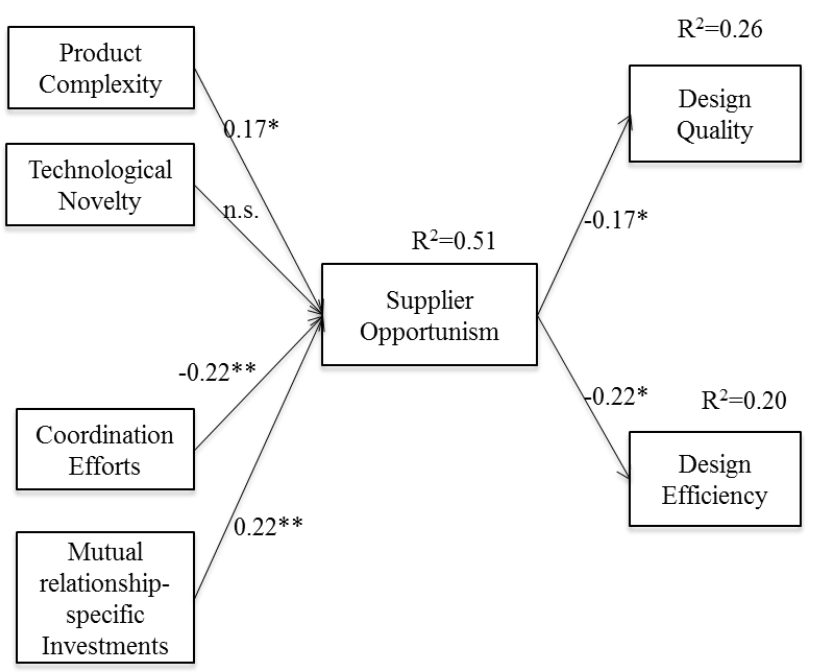

\section{China}

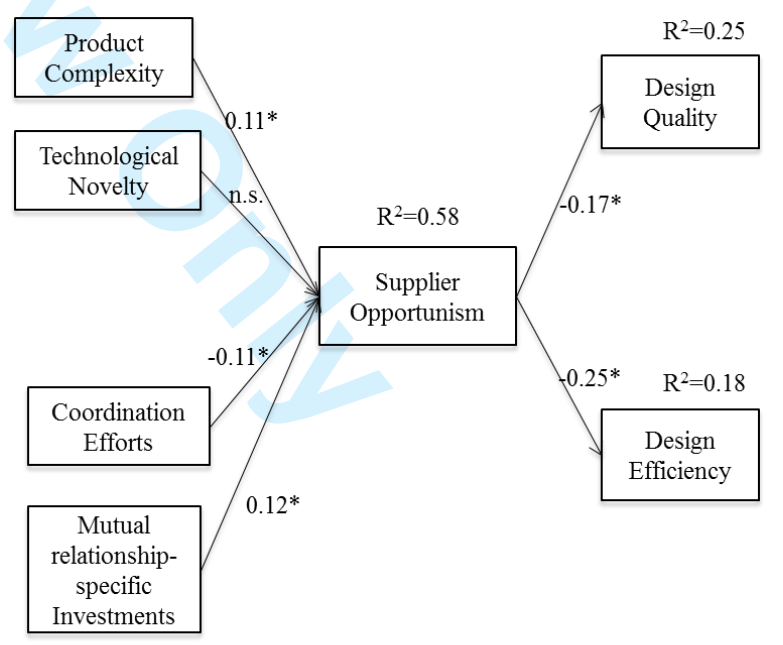

Chi-square $(2406)=3611.09$

RMSEA $=0.049$

$\mathrm{NFI}=0.90$

$\mathrm{CFI}=0.96$

IFI $=0.96$

$\mathrm{SRMR}=0.075$ (US), 0.083 (China)

GFI $=0.87$ (US), 0.87 (China) 